\title{
Specificity of Nonribosomal Peptide Synthetases in the Biosynthesis of the Pseudomonas virulence factor
}

Supporting Information

Gina L. Morgan, Ashley M. Kretsch, Kevin C. Santa Maria, Savannah J. Weeks, Bo Li

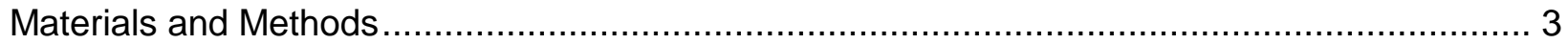

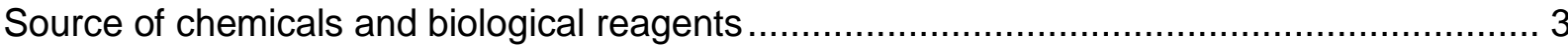

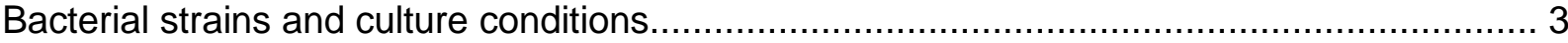

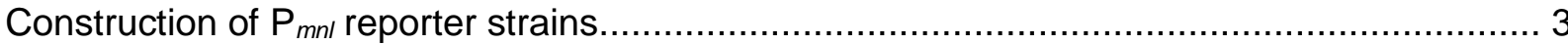

Growth of bacterial strains containing $p v f C$ of different 10-AA codes ................................. 3

$\beta$-galactosidase assay to test for signaling activity...................................................... 4

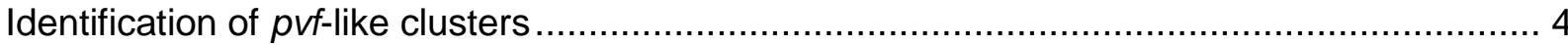

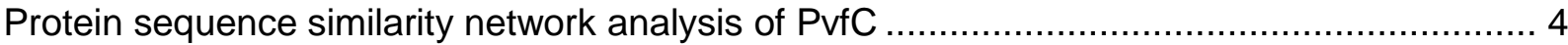

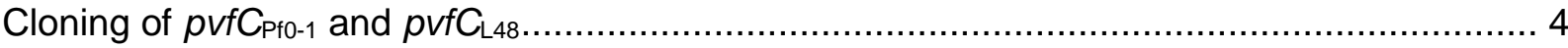

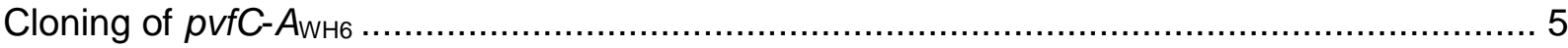

Cloning of $p v f C_{\mathrm{Pf0}-1}$ single point mutants (M429V, M429C, M429T, M429I) ......................... 5

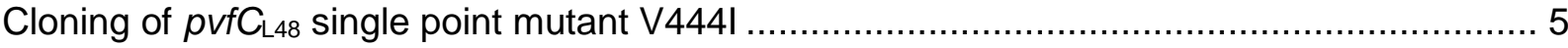

Cloning of $p v f C_{P f 0-1}-S 366 A$, I369L, M429V, L452I (ALVI) …............................................ 5

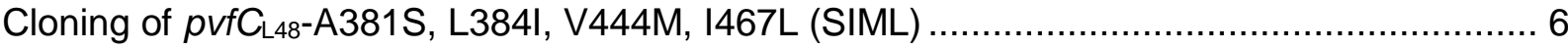

Expression and purification of $\mathrm{N}$-term His-tagged PvfC homologs and mutants.................... 6

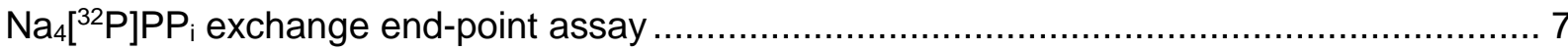

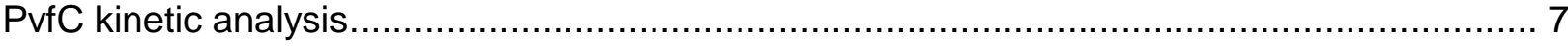

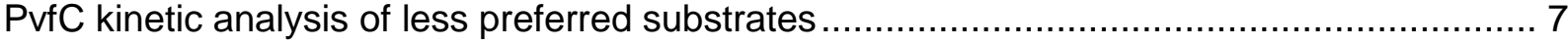

Circular dichroism (CD) analysis of $\mathrm{PvfC}_{\mathrm{L} 48}-\mathrm{WT}$ and SIML mutant and $\mathrm{PvfC}_{\mathrm{Pf0}-1}-\mathrm{WT}$ and ALVI mutant

\section{Supplementary Tables}

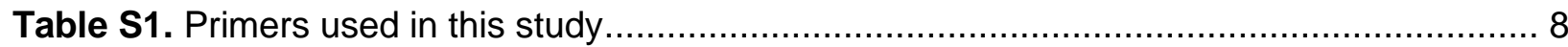

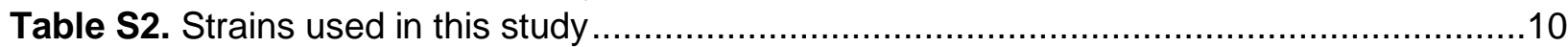

Table S3. 10-AA code of PvfC homologs.................................................................

Table S4. Number of amino acids different between each 10-AA code..............................11

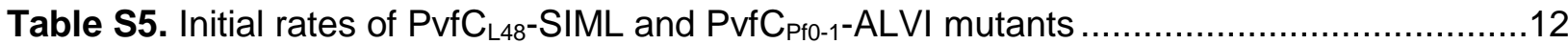

Table S6. Accession IDs of proteins used in this study ................................................12 


\section{Supplementary Figures}

Figure S1. Incorporation of amino acids into small molecules produced by pvf-encoded enzymes

Figure S2. Fresh media control does not complement $L 48 \Delta p v f C:: \mathrm{P}_{m n 1}-l a c Z$.........................14

Figure S3. SDS-PAGE analyses of all proteins used in this study .......................................15

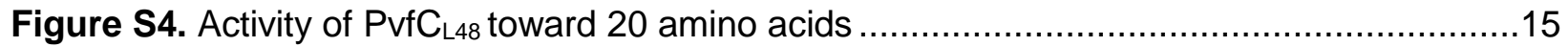

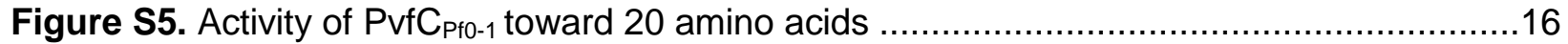

Figure S6. Steady-state kinetic analysis of $\mathrm{PvfC}_{\mathrm{L} 48}$ toward L-Leu and L-Ile ............................16

Figure S7. Steady-state kinetic analysis of PvfC $\mathrm{Pft}_{1}$ toward L-Val .....................................17

Figure S8. Activity of PvfC-AwH6 toward 20 amino acids ...............................................17

Figure S9. Steady-state kinetic analysis of PvfC-AwH6 toward L-Leu.....................................18

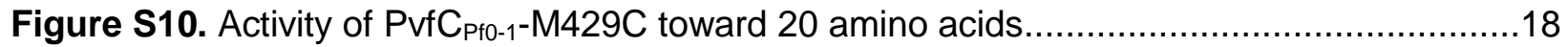

Figure S11. Steady-state kinetic analysis of PvfC $\mathrm{Pf0}_{-1}-\mathrm{M} 429 \mathrm{C}$ toward L-Leu and L-Val..............19

Figure S12. Activity of $\mathrm{PvfC}_{\mathrm{Pf0}-1}-\mathrm{M} 429 \mathrm{I}$ toward 20 amino acids .......................................19

Figure S13. Steady-state kinetic analysis of PvfC $\mathrm{Pf0}_{0-1}-\mathrm{M} 429 \mathrm{I}$ toward L-Leu ............................20

Figure S14. Activity of $\mathrm{PvfC}_{\mathrm{Pf0}-1}-\mathrm{M} 429 \mathrm{~T}$ toward 20 amino acids ..........................................20

Figure S15. Steady-state kinetic analysis of PvfC $\mathrm{Pf0}_{-1}-\mathrm{M} 429 \mathrm{~T}$ toward L-Leu and L-Val ..............21

Figure S16. Activity of $\mathrm{PvfC}_{\mathrm{Pf0}-1}-\mathrm{M} 429 \mathrm{~V}$ toward 20 amino acids .......................................21

Figure S17. Steady-state kinetic analysis of PvfC $\mathrm{Pf0}_{-1}-\mathrm{M} 429 \mathrm{~V}$ toward L-Leu and L-Val..............22

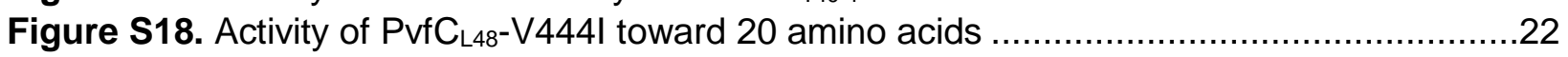

Figure S19. Steady-state kinetic analysis of $\mathrm{PvfC}_{\mathrm{L} 48} \mathrm{~V}$-V444I toward L-Val, L-Leu, and L-Ile .........23

Figure S20. Steady-state kinetic analysis of $\mathrm{PvfC}_{\mathrm{L} 48}$-A381S, L384I, V444M, I467L (SIML)

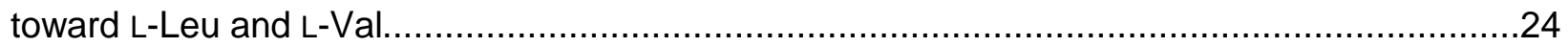

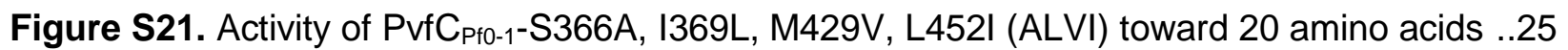

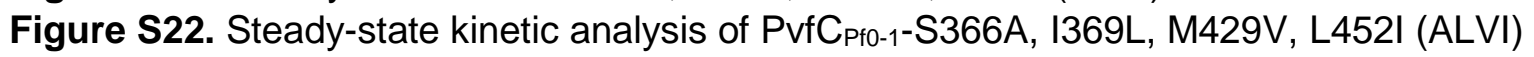

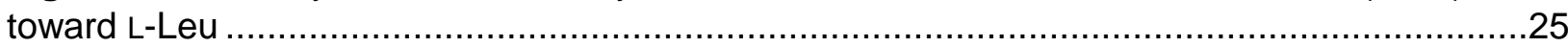

Figure S23. Circular dichroism spectra of $\mathrm{PvfC}_{\llcorner 48}$ and $\mathrm{PvfC}_{\llcorner 48}-\mathrm{A} 381 \mathrm{~S}, \mathrm{~L}$.384I, V444M, I467L

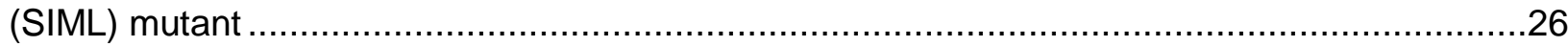

Figure S24. Circular dichroism spectra of $\mathrm{PvfC}_{\mathrm{Pf0}-1}$ and PvfC $\mathrm{Pf0}_{\mathrm{P}-1} \mathrm{~S} 366 \mathrm{~A}, \mathrm{I369L}, \mathrm{M} 429 \mathrm{~V}, \mathrm{~L} 452 \mathrm{I}$

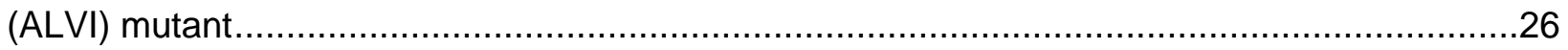

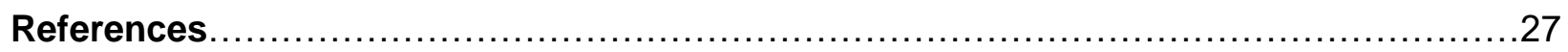




\section{Materials and Methods}

\section{Source of chemicals and biological reagents}

Chemicals were purchased from Sigma or Fisher Scientific unless otherwise stated. $\mathrm{Na}_{4}\left[{ }^{32} \mathrm{P}\right] \mathrm{PPi}$ was purchased from Perkin Elmer. Polymerase chain reactions (PCR) were conducted using Q5 DNA polymerase (New England Biolabs, NEB) and PCR products were isolated using either the PCR cleanup kit (QIAGEN) or DNA gel extraction kit (Zymo Research) after excision from an agarose gel containing ethidium bromide. Ligations were performed using T4 DNA ligase (NEB) overnight at $16{ }^{\circ} \mathrm{C}$. E. coli electrocompetent cells were transformed by electroporation. E. coli chemically competent cells were transformed by heat shock. Plasmids were isolated from overnight cultures using the GeneJet plasmid miniprep kit (Thermo Scientific) and verified by DNA sequencing (Eton Biosciences).

\section{Bacterial strains and culture conditions}

E. coli TOP 10 or BL21 was grown in Miller Luria Broth at $37^{\circ} \mathrm{C}$. Antibiotics were used at the following concentrations in both liquid and solid growth media: kanamycin $50 \mu \mathrm{g} \mathrm{mL}^{-1}$, or chloramphenicol $34 \mu \mathrm{g} \mathrm{mL}^{-1}$. Antibiotics and IPTG were purchased from GoldBio.

\section{Construction of $\mathbf{P}_{m n l}$ reporter strains}

To construct the promoter cassettes, a $500 \mathrm{bp} 5$ ' region to $\mathrm{mnl}$ was amplified using primers AKp184 and AKp237 and inserted upstream of lacZ on the pUC-lacZ suicide plasmid. ${ }^{1-2}$ Wildtype (WT) and pvf knockout $(\triangle p v f C)$ strains of $P$. entomophila $L 48$ were transformed as described below with this plasmid, along with a helper vector pTNS3. The $m n$ l-lac $Z$ cassette was inserted at the single Tn7 site upstream of GlmS. Insertion was verified by colony PCR using primers AKp196/AKp205 and AKp254/AKp205.

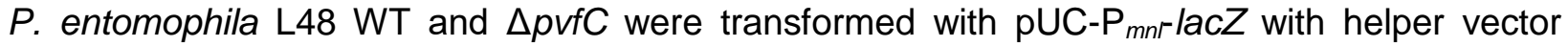
pTNS3 using an electroporation method. ${ }^{3}$ Briefly, $6 \mathrm{~mL}$ overnight cultures of Pseudomonas were divided into four $1.5 \mathrm{~mL}$ microcentrifuge tubes and the cells were harvested at $6000 \mathrm{xg}$ for 5 minutes. After removal of the supernatant, the cells were washed twice with $1 \mathrm{~mL}$ of $300 \mathrm{mM}$ sucrose in each tube. The cell pellets were combined and resuspended in $100 \mu \mathrm{L}$ of $300 \mathrm{mM}$ sucrose to generate electrocompetent cells. An aliquot of $50 \mu \mathrm{L}$ cells in sucrose was gently mixed with $1 \mu \mathrm{L}$ of $200 \mathrm{ng} \mathrm{\mu L}^{-1}$ plasmid and transformed by electroporation (2.0 keV in $1 \mathrm{~mm}$ cuvettes). Transformed cells were recovered in $1 \mathrm{~mL}$ LB for 2 hours while shaking at a speed of $225 \mathrm{rpm}$. A sample of $150 \mu \mathrm{L}$ of the cell suspension was plated on LB agar containing kanamycin and x-gal and incubated at $28^{\circ} \mathrm{C}$ for 1 day until colonies appeared. Blue colonies were selected and verified by PCR of the genomic DNA.

\section{Growth of bacterial strains containing pvfC of different 10-AA codes}

$P$. entomophila L48 and B. cenocepacia HI2424 were grown in Lennox LB (LSLB), $P$. syringae pv. tomato DC3000 was grown in King's medium B, and $P$. fluorescens Pf0-1 and $P$. fluorescens WH6 were grown in Miller Luria Broth. Samples of $5 \mathrm{~mL}$ overnight cultures were grown at $28^{\circ} \mathrm{C}$ to saturation. These cultures $(2 \mathrm{~mL}$ for DC3000 cultures and $0.5 \mathrm{~mL}$ for the rest) were used to inoculated $25 \mathrm{~mL}$ cultures. The $25 \mathrm{~mL}$ cultures were grown at $28{ }^{\circ} \mathrm{C}$ and $225 \mathrm{RPM}$ for 24 hours. Cells were then harvested by centrifugation at $4500 \times \mathrm{g}$ for 30 minutes and supernatant was filtered with a $0.20 \mu \mathrm{M}$ syringe filter to obtain the cell-free supernatant. 


\section{$\beta$-galactosidase assay to test for signaling activity}

Samples of $4 \mathrm{~mL}$ cultures of $P$. entomophila L48 $\mathrm{P}_{m n r}$ lac $Z$ and $P$. entomophila L48 $\Delta$ pvfC $\mathrm{P}_{\mathrm{mrr}}$ lacZ were grown overnight to saturation. Samples of $10 \mu \mathrm{L}$ of these cultures were used to inoculate $4 \mathrm{~mL}$ LSLB cultures containing kanamycin. To test for complementation of signaling activity, $1 \mathrm{~mL}$ of cell-free supernatant of bacterial strains of interest obtained as described above was added to a $4 \mathrm{~mL}$ culture inoculated with $P$. entomophila $L 48 \Delta p v f C \mathrm{P}_{m n r} l a c Z$ in a 1:5 ratio of cell free supernatant to total volume. Control cultures were also grown, adding $1 \mathrm{~mL}$ fresh media to $4 \mathrm{~mL}$ cultures. Cultures were grown at $28{ }^{\circ} \mathrm{C}$ and $225 \mathrm{RPM}$ for 24 hours. Following growth, $\mathrm{OD}_{600}$ was measured for each culture and $100 \mu \mathrm{l}$ of each culture was spun at $3500 \mathrm{xg}$ for $5 \mathrm{~min}$, pellet was resuspended in $\mathrm{Z}$ buffer $\left(60 \mathrm{mM} \mathrm{NaH} \mathrm{PO}_{4} \cdot 7 \mathrm{H}_{2} \mathrm{O}, 40 \mathrm{mM} \mathrm{NaH} \mathrm{PO}_{4} \cdot \mathrm{H}_{2} \mathrm{O}, 10 \mathrm{mM} \mathrm{KCl}\right.$, $1 \mathrm{mM} \mathrm{MgSO} \cdot \mathrm{H}_{2} \mathrm{O}$ ), 25 to $500 \mu \mathrm{L}$ of resuspended mixtures was diluted to final volume of $1 \mathrm{~mL}$. Cells were then lysed with $100 \mu \mathrm{l}$ of chloroform and $50 \mu \mathrm{L} 0.1 \%$ SDS for $5-10$ minutes. To initiate the reaction, $200 \mu \mathrm{L}$ of ortho-nitrophenyl- $\beta$-galactoside $\left(4 \mathrm{mg} \mathrm{mL}^{-1}\right)$ was added and reaction was incubated at $28{ }^{\circ} \mathrm{C}$ and 600 RPM. As soon as yellow color appeared reaction was quenched with $500 \mu \mathrm{L}$ sodium carbonate $(1 \mathrm{M})$. Reactions were then spun at $20,000 \times \mathrm{g}$ for 10 minutes. Absorbances at 420 and $550 \mathrm{~nm}$ were measured. Miller units were calculated according to the following equation: Miller units $=1000 * \frac{A b s 420-1.75 * A b s 550}{\text { time } * v o l u m e * O D 600}$

\section{Identification of pvf-like clusters}

Pvf-like clusters were identified by using the pvf homolog from Burkholderia cenocepacia J2315 as a query for a MultiGeneBlast ${ }^{4}$ architecture search (finds genomic loci that contain a specified set of genes) against an NCBI GenBank Database as curated in 12/2015. A cut-off cumulative BLAST bit score of 1150 was applied to remove unrelated clusters.

Pvf-like clusters were identified in strains deposited in the Pseudomonas Genome Database. ${ }^{5}$ Pvf from Pseudomonas entomophila L48 was used as a query for a MultiGeneBlast ${ }^{4}$ architecture search against the 2560 Pseudomonas genomes available from the Pseudomonas Genome Database as of 1/25/2017. The same cut-off scores from phylogenetic tree generation were then applied to pvf-like clusters identified.

\section{Protein sequence similarity network analysis of PvfC}

Sequence similarity network (SSN) was constructed using the Enzyme Function Initiated-Enzyme similarity tool (EFI-EST, http://efi.igb.illinois.edu/efi-est). ${ }^{6}$ FASTA sequences of PvfC homologs from all 308 pvf-containing strains were uploaded to EFI-EST. The SSN was made using an alignment score of 550. SSN was visualized using Cytoscape.

\section{Cloning of $p v f C_{\mathrm{Pf0}-1}$ and $p v f C_{\mathrm{L} 48}$}

The $p v f C_{L 48}$ gene was amplified from $P$. entomophila $L 48$ genomic DNA using primers GM065 and GM066 and cloned into the pET28a vector. The $p v f C_{\text {Pf0-1 }}$ gene was amplified from $P$. fluorescens Pf0-1 genomic DNA using primers GM051 and GM052. These PCR products were purified and digested with restriction enzymes BamHI and Notl and then ligated into pET28a using corresponding restriction sites. E. coli Top 10 or E. coli DH5a were transformed with the ligation mixtures for cloning. The resulting plasmids, $\mathrm{pET} 28 \mathrm{a}-p v f C_{\mathrm{L} 48}$ and $\mathrm{pET} 28 \mathrm{a}-p v f C_{\mathrm{Pf0}-1}$ were verified by DNA sequencing (Eton Biosciences). 


\section{Cloning of pvfC-A $A_{\mathrm{wH} 6}$}

The gene $p v f C-A_{\mathrm{WH}}$ was amplified from $P$. fluorescens WH6 genomic DNA using primers GM046 and GM050. Purified PCR product was digested with restriction enzymes EcoRI and HindlII and ligated into $\mathrm{pACYC}$-duet1 using corresponding restriction sites. E. coli Top10 or E. coli DH5a were transformed with the ligation mixtures for cloning. The resulting plasmid, pACYC-duet1-pvfC $C_{\mathrm{wH} 6}$ was verified by DNA sequencing.

\section{Cloning of $p v f C_{\mathrm{Pf0}-1}$ single point mutants (M429V, M429C, M429T, M429I)}

The $p v f C_{\mathrm{Pf0}-1}$ gene containing single point mutation was cloned using overlap extension PCR and ET28a-pvfC $C_{\mathrm{PfO}-1}$ as a template. Primers were designed to contain homologous regions overlapping the mutation site. Overlapping PCR products were amplified using primers GM051/GM053 and GM052/GM0GM054 (for M429V), GM052/GM055 and GM052/GM056 (for M429C), GM051/GM057 and GM052/GM058 (for M429T) and GM051/GM059 and GM052/GM060 (for M429I), respectively. PCR products were purified, then combined and the entire gene was amplified using a total of 35 cycles including an initial five two-step cycles followed by addition of primers GM051/GM052 for the remaining cycles. The purified PCR products were digested with restriction enzymes BamHI and Notl and then ligated into pET28a using corresponding restriction sites. E. coli Top10 or DH5a were transformed with the ligation mixtures for cloning. The resulting

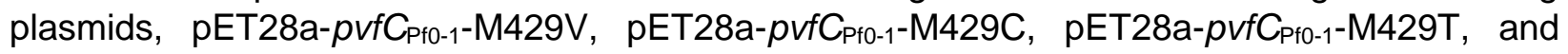
pET28a-pvfC $C_{\mathrm{Pf0}-1}-\mathrm{M} 429 \mathrm{I}$ were verified by DNA sequencing.

\section{Cloning of $p v f C_{\llcorner 48}$ single point mutant V444I}

The $p v f C_{\llcorner 48}$ gene containing the $\mathrm{V} 444 \mathrm{I}$ single point mutation was cloned using overlap extension $\mathrm{PCR}$ and $\mathrm{pET} 28 \mathrm{a}-p v f \mathrm{~L}_{\mathrm{L} 48}$ as a template. Primers were designed to contain homologous regions overlapping the mutation of interest. Overlapping PCR products were amplified using primers GM065/GM116 and GM066/GM0115 respectively. PCR products were purified, then combined and the gene was amplified using a total of 35 cycles including five two-step cycles before addition of primers GM065/GM066 for the remaining cycles. The purified PCR products were digested with restriction enzymes BamHI and Notl and then ligated into pET28a using corresponding restriction sites. E. coli Top10 or $\mathrm{DH} 5 \alpha$ were transformed with the ligation mixtures. The resulting plasmid $\mathrm{pET} 28 \mathrm{a}-\mathrm{pvf} \mathrm{C}_{\mathrm{L} 48} \mathrm{-} \mathrm{V} 444 \mathrm{I}$ was verified by DNA sequencing.

\section{Cloning of $p v f C_{P f 0-1}-S 366 A$, I369L, M429V, L452I (ALVI)}

The pvfC $C_{\mathrm{Pf0}-1}$ gene containing the-S366A, I369L, M429V, L452I (ALVI) quadruple mutations was cloned using three-piece overlap extension PCR andpET28a-pvfC Pf0-1 $_{1-M 429 V}$ as a template. Primers were designed to contain homologous regions overlapping the mutation of interest Overlapping PCR products were amplified using GM051/GM061, GM062/GM064, and GM063/GM052. PCR products were purified, then combined and the full gene was amplified using a total of 35 cycles including five two-step cycles before addition of primers GM051/GM052 for the remaining cycles. The purified PCR products were digested with restriction enzymes BamHI and Notl and then ligated into pET28a using corresponding restriction sites. E. coli Top10 orDH5a were transformed with the ligation mixtures for cloning. The resulting plasmid, $p E T 28 a-p v f C_{\mathrm{Pf0}-1^{-}}$ S366A, I369L, M429V, L452I (ALVI) was verified by DNA sequencing. 


\section{Cloning of $p v f C_{\mathrm{L} 48}-\mathrm{A} 381 \mathrm{~S}, \mathrm{L384I}, \mathrm{V444M}$, I467L (SIML)}

Two plasmids were made to clone $p$ f $_{\mathrm{L} 48}$-A381S, L384I, V444M, I467L (SIML): pET28a-

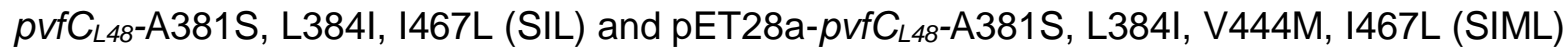

The $p v f C_{\mathrm{L} 48}$ gene containing the -A381S, L384I, I467L (SIL) triple mutations was cloned using three-piece overlap extension PCR and pET28a-pvfC-L48 as a template. Primers were designed to contain homologous regions overlapping the mutation of interest Overlapping PCR products were amplified using GM065/GM070, GM069/GM072, and GM071/GM066. PCR products were purified, then combined and the full gene was amplified using a total of 35 cycles including five two-step cycles before addition of primers GM065/GM066 for the remaining cycles. The purified PCR products were digested with restriction enzymes BamHI and Notl and then ligated into pET28a using corresponding restriction sites. E. coli Top10 or DH5a were transformed with the ligation mixtures for cloning. The resulting plasmid, $p v f C_{\llcorner 48}-A 381 S$, L384I, I467L (SIL) was verified by DNA sequencing.

The $p v f C_{\mathrm{L} 48}$ gene containing the -A381S, L384I, V444M, I467L (SIML) quadruple mutations was cloned using two-piece overlap extension PCR and pET28a-pvfCL48-A381S, L384I, I467L (SIL) as a template. Primers were designed overlapping the mutation of interest. PCR products were amplified using GM065/GM068 and GM067/GM066. PCR products were purified, then combined and the full gene was amplified using a total of 35 cycles including five two-step cycles before addition of primers GM065/GM066 for the remaining cycles. The purified PCR products were digested with restriction enzymes BamHI and Notl and then ligated into pET28a using corresponding restriction sites. E. coli Top10 or DH5 $\alpha$ were transformed with the ligation mixtures for cloning. The resulting plasmid, pET28a-pvfC $C_{\llcorner 48}-A 381 S$, L384I, V444M, I467L (SIML) was verified by DNA sequencing.

\section{Expression and purification of $\mathbf{N}$-term His-tagged PvfC homologs and mutants}

A sample of $1 \mathrm{~L}$ of Luria Broth containing kanamycin (or chloramphenicol for $p v f C-A_{\mathrm{WH}}$ ) was inoculated with $5 \mathrm{~mL}$ of overnight cultures and grown at $37^{\circ} \mathrm{C}$ until $\mathrm{OD}_{600}$ reached $0.5-0.6$. Protein expression was induced with $0.5 \mathrm{mM}$ of IPTG and the cells were grown overnight at $16{ }^{\circ} \mathrm{C}$ post induction. Cells were harvested by centrifugation at $4500 \mathrm{xg}$. His 6 -tagged proteins were purified by nickel affinity chromatography and size exclusion chromatography using an Akta FPLC. Cell pellet was resuspended in $15 \mathrm{~mL}$ of wash buffer and lysed using a Branson sonicator at $30 \%$ amplitude for 1.5 min of total 'on' time, cycling between $0.5 \mathrm{sec}$ on and $1.5 \mathrm{sec}$ off. Cell debris was pelleted at $35,000 \times \mathrm{g}$ and supernatant was filtered through a $0.45 \mu \mathrm{m}$ syringe filter and injected onto a GE $5 \mathrm{~mL}$ His Trap HP Column. The His ${ }_{6}$-tagged protein was eluted over a gradient of $5300 \mathrm{mM}$ imidazole. Fractions containing proteins of interest were identified by SDS-PAGE analysis, pooled, and concentrated with an Amicon centrifugal concentrator to $5 \mathrm{~mL}$ or less. The concentrated proteins were applied on a GE Superdex 200 size exclusion column for further purification into storage buffer (Wash buffer with no imidazole). Protein was flash frozen in beads in liquid nitrogen and stored at $-80^{\circ} \mathrm{C}$.

Wash buffers for each protein are as follows:

PvfC $_{\text {Pfo-1: }}$ : $50 \mathrm{mM}$ HEPES, $5 \mathrm{mM}$ imidazole, $300 \mathrm{mM} \mathrm{NaCl}, 10 \%$ glycerol, $\mathrm{pH}=8.0$ )

PvfC $_{\text {Pfo-1 }}-\mathrm{M} 429 \mathrm{~V}$ : (50 mM HEPES, $5 \mathrm{mM}$ imidazole, $300 \mathrm{mM} \mathrm{NaCl}, 10 \%$ glycerol, pH=7.5)

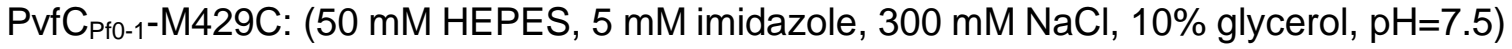




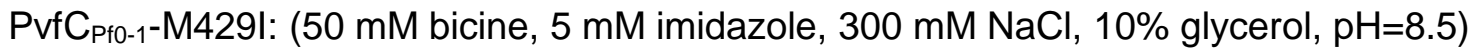

PvfC $_{\text {Pfo-1 }}-\mathrm{M} 429 \mathrm{~T}$ : (50 mM HEPES, $5 \mathrm{mM}$ imidazole, $300 \mathrm{mM} \mathrm{NaCl}, 10 \%$ glycerol, $\mathrm{pH}=7.5$ )

PvfC ${ }_{\text {Pfo-1 }}-\mathrm{ALVI}$ : (50 mM bicine, $5 \mathrm{mM}$ imidazole, $300 \mathrm{mM} \mathrm{NaCl}, 10 \%$ glycerol, $\mathrm{pH}=9.0$ )

$P_{\text {vfC }}{ }_{488}$ : $(50 \mathrm{mM}$ bicine, $5 \mathrm{mM}$ imidazole, $300 \mathrm{mM} \mathrm{NaCl}, 10 \%$ glycerol, $\mathrm{pH}=9.0$ )

$P_{\text {PfC }}{ }_{48}$-V444I: (50 mM HEPES, 5 mM imidazole, $300 \mathrm{mM} \mathrm{NaCl}, 10 \%$ glycerol, $\mathrm{pH}=8.0$ )

PvfC 448 -SIML: (50 mM bicine, $5 \mathrm{mM}$ imidazole, $300 \mathrm{mM} \mathrm{NaCl}, 10 \%$ glycerol, $\mathrm{pH}=9.0$ )

PvfC-A $\mathrm{WH}_{\mathrm{W}}$ : $\left(20 \mathrm{mM} \mathrm{NaH}_{2} \mathrm{PO}_{4}, 20 \mathrm{mM}\right.$ imidazole, $300 \mathrm{mM} \mathrm{NaCl}, 10 \%$ glycerol, $\left.\mathrm{pH}=7.4\right)$

\section{$\mathrm{Na}_{4}\left[{ }^{32} \mathrm{P}\right] \mathrm{PP}$ i exchange end-point assay to identify adenylation specificity of PvfC homologs and mutants}

To identify the selectivity of the adenylation (A) domain, PvfC $(5 \mu \mathrm{M})$ was incubated with $4 \mathrm{mM}$ amino acid substrate, $1 \mathrm{mM} \mathrm{Na} 4\left[{ }^{32} \mathrm{P}\right] \mathrm{PPi}(100,000-200,000$ CPM per reaction), in $50 \mathrm{mM}$ HEPES $(\mathrm{pH}=7.5)$ buffer containing $1 \mathrm{mM} \mathrm{MgCl} 2,1 \mathrm{mM} \mathrm{ATP}$, and $4 \mathrm{mM}$ cold sodium pyrophosphate $\left(\mathrm{PP}_{\mathrm{i}}\right)$. Each proteinogenic amino acid was tested as a substrate. Reaction was initiated with the addition of enzyme and incubated for 1 hour at room temperature. Reaction was stopped using $500 \mu \mathrm{L}$ quenching solution ( $1.6 \%$ activated charcoal, $3.5 \% \mathrm{HClO}_{4}, 0.1 \mathrm{M} \mathrm{Na}{ }_{4} \mathrm{PPi}$ ) to halt reaction and bind [32P]ATP to the activated charcoal. Mixture was centrifuged for $8 \mathrm{~min}$ at max rcf to remove unreacted $\mathrm{Na}_{4}\left[{ }^{32} \mathrm{P}\right] \mathrm{PP}_{\mathrm{i}}$. Supernatant was decanted and charcoal pellet was resuspended in $1 \mathrm{~mL}$ of water. Mixture was centrifuged for $8 \mathrm{~min}$ at $\max \mathrm{rcf}$ and decanted. Charcoal pellet was resuspended in $500 \mu \mathrm{L}$ water and added to $10 \mathrm{~mL}$ of scintillation fluid (ScintiVerse BD Cocktail). A Beckman LS 6500 scintillation counter was used to measure the charcoal-bound radioactivity.

\section{PvfC kinetic analysis}

The $\mathrm{Na}_{4}\left[{ }^{32} \mathrm{P}\right] \mathrm{PP}$ exchange assay was performed using $0.5 \mu \mathrm{M}$ PvfC and increasing concentrations of L-leucine or L-valine $(0 \mathrm{mM}, 0.1 \mathrm{mM}, 0.5 \mathrm{mM}, 1 \mathrm{mM}, 5 \mathrm{mM}$, and $10 \mathrm{mM})$. A 600 $\mu \mathrm{L}$ master mix was prepared for each substrate concentration. The remaining assay components were the same as the end-point assay. An aliquot of $100 \mu \mathrm{L}$ was removed at $0,5,10,15$, and 20 minutes from each reaction and immediately quenched with quenching solution described for the end-point assay. The remaining work up of the reaction is the same as described for the endpoint assay. A Beckman LS 6500 scintillation counter was used to measure the charcoal-bound radioactivity. Initial velocity and kinetic calculations were calculated using GraphPad Prism.

\section{PvfC kinetic analysis of less preferred substrates}

The $\mathrm{Na}_{4}\left[{ }^{32} \mathrm{P}\right] \mathrm{PP}$ i exchange assay was performed using the same method as described in PvfC kinetic analysis with the exception of using $2 \mu \mathrm{M}$ of respective PvfC homolog and increasing concentrations of L-leucine, L-valine, or L-isoleucine $(0 \mathrm{mM}, 0.1 \mathrm{mM}, 0.5 \mathrm{mM}, 1 \mathrm{mM}, 5 \mathrm{mM}$, and $10 \mathrm{mM}$ ) and 300,000-400,000 CPM per reactions. Substrates for which $k_{\text {cat }}$ was less than $1.5 \mathrm{~s}^{-1}$ were less preferred than the native substrate.

\section{Circular dichroism (CD) analysis of $\mathrm{PvfC}_{\mathrm{L} 48}-\mathrm{WT}$ and SIML mutant and PvfC $\mathrm{Pf0}-1_{\mathrm{P}}-\mathrm{WT}$ and ALVI mutant}

Buffer exchange of PvfC and mutants were conducted using PD-10 desalting columns into buffer designed for $\mathrm{CD}$ experiments (10 mM NaH $\mathrm{PO}_{4} / \mathrm{Na}_{2} \mathrm{HPO}_{4}, \mathrm{pH}=7.5$ ). Samples were diluted to a final concentration of $2 \mu \mathrm{M}$. Spectra were recorded from $180-280 \mathrm{~nm}$, with a step of $0.5 \mathrm{sec}$ and 1 second per point, using a Chirascan plus Circular Dichroism Spectrophotometer. 
Table S1. Primers used in this study.

\begin{tabular}{|c|c|c|}
\hline Description & Name & 5' to 3' sequence \\
\hline $\begin{array}{l}P \text {. ent L48 } \mathrm{mnl} \\
\text { promoter region, } \\
\text { Fwd (EcoRI) }\end{array}$ & AKp184 & ATCGGAATTCCCTTCATGGGAAGTGGAAG \\
\hline $\begin{array}{l}P . \text { ent } \mathrm{L} 48 \mathrm{mnl} \\
\text { promoter region, } \\
\text { Rev (HindlII) }\end{array}$ & AKp237 & CGATAAGCTTCCTTGATCGTCATCGTCCTTC \\
\hline $\begin{array}{l}\text { Kanamycin Fwd } \\
\text { diagnostic for pUC- } \\
\text { lacZ insertion }\end{array}$ & AKp196 & TTTAGCAGCCCTTGCGCC \\
\hline $\begin{array}{l}\text { GImS Fwd (to } \\
\text { PTn7R) }\end{array}$ & AKp205 & CGATCCTCTACACCATTCCG \\
\hline lacZRev & AKp254 & AGG TTA CGT TGG TGT AGA TGG G \\
\hline $\begin{array}{l}p_{f f C_{\mathrm{WH}}} \mathrm{Fwd} \\
\text { (EcoRI) }\end{array}$ & GM046 & GATCGATCGAATTCGATGAAGCGTCTGAGGATCG \\
\hline $\begin{array}{l}\text { pvfC-AwH6 Rev } \\
\text { (HindlII) }\end{array}$ & GM050 & GATCGATCAAGCTTTCACCACAACTGAGTCAATTGCG \\
\hline $\begin{array}{l}\text { pvfC } C_{\text {Pf0-1 }} \text { Fwd } \\
\text { (BamHI) }\end{array}$ & GM051 & GATCGATCGGATCCGACAAGGAGGCTGACATGAGACGT \\
\hline$p v f C_{\text {Pf0-1 }} \operatorname{Rev}($ Notl) & GM052 & $\begin{array}{l}\text { GATCGATCGCGGCCGCTCAGATGAAGTTGA } \\
\text { TTTCTTTCAGGTAGTCGC }\end{array}$ \\
\hline $\begin{array}{l}\text { pvfC } C_{\text {Pf0-1 }} \text { Rev } \\
\text { overlap M429V }\end{array}$ & GM053 & GGTCACGATCTGTCCGACGCTTTG \\
\hline $\begin{array}{l}\text { pvfC } C_{\text {Pfo-1 }} \text { Fwd } \\
\text { overlap M429V }\end{array}$ & GM054 & GGACAGATCGTGACCGGCGG \\
\hline $\begin{array}{l}\text { pvfC } C_{\text {Pfo-1 }} \text { Rev } \\
\text { overlap M429C }\end{array}$ & GM055 & CGGTACAGATCTGTCCGACGCTTTG \\
\hline $\begin{array}{l}\text { pvfC } C_{\text {Pfo-1 }} \text { Fwd } \\
\text { overlap M429C }\end{array}$ & GM056 & GGACAGATCTGTACCGGCGGC \\
\hline $\begin{array}{l}\text { pvfC } C_{\text {Pfo-1 }} \text { Rev } \\
\text { overlap M429T }\end{array}$ & GM057 & GGTCGTGATCTGTCCGACGCTTTG \\
\hline $\begin{array}{l}\text { pvf }_{\text {Pf0-1 }} \text { Fwd } \\
\text { overlap M429T }\end{array}$ & GM058 & GGACAGATCACGACCGGCGGC \\
\hline $\begin{array}{l}\text { pvfC } C_{\mathrm{Pf0}-1} \text { Rev } \\
\text { overlap M429l }\end{array}$ & GM059 & CGGTGATGATCTGTCCGACGCTTTG \\
\hline $\begin{array}{l}\text { pvfC } C_{\text {Pf0-1 }} \text { Fwd } \\
\text { overlap M429l }\end{array}$ & GM060 & GGACAGATCATCACCGGCGGC \\
\hline $\begin{array}{l}p v f C_{\text {Pfo-1 }} \text { Rev } \\
\text { overlap S366A } \\
\text { I369L }\end{array}$ & GM061 & GGAAAATATCGAGCAGCGACGCGTC \\
\hline $\begin{array}{l}\text { pvfC } C_{\text {Pfo-1 }} \text { Fwd } \\
\text { overlap S366A } \\
\text { I369L }\end{array}$ & GM062 & TTTTGACGCGTCGCTGCTCGAT \\
\hline $\begin{array}{l}\text { pvfC } C_{\text {Pf0-1 }} \text { Fwd } \\
\text { overlap L452I }\end{array}$ & GM063 & CACAACATCTACGGCCCGACCG \\
\hline
\end{tabular}




\begin{tabular}{|c|c|c|}
\hline $\begin{array}{l}\text { pvfC } C_{\text {Pfo-1 }} \text { Rev } \\
\text { overlap L452I }\end{array}$ & GM064 & CTTCGGTCGGGCCGTAGATGTT \\
\hline $\begin{array}{l}p v f C_{\llcorner 48} \text { Fwd } \\
(\mathrm{BamHI})\end{array}$ & GM065 & $\begin{array}{l}\text { GATCGATC GGATCC } \\
\text { ATGAGACGCCTCGACATACTCCTGG }\end{array}$ \\
\hline$p v f C_{\mathrm{L} 48} \operatorname{Rev}($ Notl $)$ & GM066 & $\begin{array}{l}\text { GATCGATC GCGGCCGC } \\
\text { TCAGATGAAGCCGATGTCGGCC }\end{array}$ \\
\hline $\begin{array}{l}\text { pvfC } C_{\llcorner 48} \text { Fwd overlap } \\
\text { V444I }\end{array}$ & GM115 & TGAAGCATCTGATCACTGGCGGC \\
\hline $\begin{array}{l}\text { pvfC } C_{\mathrm{L} 48} \text { Rev overlap } \\
\text { V444I }\end{array}$ & GM116 & GACATCGCCGCCAGTGATCAGAT \\
\hline $\begin{array}{l}\text { pvf } C_{\llcorner 48} \text { Fwd overlap } \\
\text { V444M }\end{array}$ & GM067 & TGAAGCATCTGATGACTGGCGGC \\
\hline $\begin{array}{l}p v f C_{\mathrm{L} 48} \text { Rev overlap } \\
\text { V444M }\end{array}$ & GM068 & GACATCGCCGCCAGTCATCAGAT \\
\hline $\begin{array}{l}p_{v f C_{\llcorner 48}} \text { Fwd overlap } \\
\text { A381S L384I }\end{array}$ & GM069 & CGGCTTCGACTCTTCCCTGATCGATA \\
\hline $\begin{array}{l}\text { pvfC } C_{\llcorner 48} \text { Rev overlap } \\
\text { A381S L384I }\end{array}$ & GM070 & GCAGGATATCGATCAGGGAAGAGTCGA \\
\hline $\begin{array}{l}p v f C_{\mathrm{L} 48} \text { Fwd overlap } \\
\text { 1467L }\end{array}$ & GM071 & GGATGCACAACCTCTATGGCCCG \\
\hline $\begin{array}{l}\text { pvfC } \mathrm{L}_{\mathrm{L} 88} \text { Rev overlap } \\
\text { 1467L }\end{array}$ & GM072 & GTTTCGGTCGGGCCATAGAGGTTG \\
\hline
\end{tabular}


Table S2. Strains used in this study.

\begin{tabular}{|c|c|c|c|}
\hline Name & Strain & Plasmid & Reference \\
\hline AK146b & P. entomophila L48:: $P_{\text {mnl-lacZ }}$ & None & This study \\
\hline AK152b & P. entomophila $\mathrm{L} 48 \Delta p v f C:: \mathrm{P}_{m n l}-$ lacZ & None & This study \\
\hline SJW001 & E. coli Top 10 & pACYC-duet1-pvfC- $A_{\mathrm{wH}}$ & This study \\
\hline SJW002 & E. coli BL21 & pACYC-duet1-pvfC- $A_{\mathrm{wH} 6}$ & This study \\
\hline GM141 & E. coli Top 10 & pET28a-pvfC $C_{\mathrm{Pf0}-1}$ & This study \\
\hline GM144 & E. coli BL21 & pET28a-pvfC $C_{\mathrm{Pf0}-1}$ & This study \\
\hline SJW005 & E. coli Top 10 & pET28a-pvfC $C_{\mathrm{Pf0}-1}-\mathrm{M} 429 \mathrm{~V}$ & This study \\
\hline SJW006 & E. coli BL21 & pET28a-pvfC $C_{\mathrm{Pf0}-1}-\mathrm{M} 429 \mathrm{~V}$ & This study \\
\hline SJW007 & E. coli Top 10 & pET28a-pvfC $C_{\mathrm{Pf0}-1}-\mathrm{M} 429 \mathrm{C}$ & This study \\
\hline GM134 & E. coli BL21 & pET28a-pvfC $C_{\mathrm{Pf0}-1}-\mathrm{M} 429 \mathrm{C}$ & This study \\
\hline SJW008 & E. coli Top 10 & pET28a-pvfC $C_{\text {Pf0-1 }}-M 4291$ & This study \\
\hline SJW009 & E. coli BL21 & pET28a-pvf $C_{\text {Pf0-1-M429l }}$ & This study \\
\hline SJW003 & E. coli Top 10 & pET28a-pvfC $C_{\text {Pf0-1 }}-M 429 T$ & This study \\
\hline SJW004 & E. coli BL21 & pET28a-pvf $C_{\text {Pf0-1 }}-M 429 T$ & This study \\
\hline GM146 & E. coli Top 10 & $\begin{array}{l}\text { pET28a-pvf } C_{\text {Pfo-1-S }} 366 \mathrm{~A}, \text { I369L, } \\
\text { M429V, L452I (ALVI) }\end{array}$ & This study \\
\hline GM147 & E. coli BL21 & $\begin{array}{l}\text { pET28a-pvff } C_{\text {Pft-1-S366A, I369L, }} \\
\text { M429V, L452I (ALVI) }\end{array}$ & This study \\
\hline GM142 & E. coli Top 10 & $\mathrm{pET28a}-p v f C_{\mathrm{L} 48}$ & This study \\
\hline GM143 & E. coli BL21 & pET28a-pvfC $C_{\llcorner 48}$ & This study \\
\hline GM217 & E. coli Top 10 & pET28a- $p v f C_{\mathrm{L} 48}-\mathrm{V} 444 \mathrm{I}$ & This study \\
\hline GM219 & E. coli BL21 & pET28a-pvfC $C_{\llcorner 48}-\mathrm{V} 444 \mid$ & This study \\
\hline GM140 & E. coli BL21 & $\begin{array}{l}\text { pET28a- } p v f C \text { L48-A381S, L394I, } \\
\text { 1467L (SIL) }\end{array}$ & This study \\
\hline GM139 & E. coli Top 10 & $\begin{array}{l}\text { pET28a-pvfC L48-A381S, L394I, } \\
\text { V444M, I467L (SIML) }\end{array}$ & This study \\
\hline GM138 & E. coli BL21 & $\begin{array}{l}\text { pET28a-pvfC } \mathrm{L} 48-\mathrm{A} 381 \mathrm{~S}, \mathrm{~L} 394 \mathrm{I} \\
\text { V444M, I467L (SIML) }\end{array}$ & This study \\
\hline GM064 & P. entomophila L48 & None & 7 \\
\hline GM172 & B. cenocepacia HI2424 & None & 8 \\
\hline GM066 & P. syringae pv. tomato DC3000 & None & 9 \\
\hline GM127 & P. fluorescens Pf0-1 & None & 9 \\
\hline GM112 & P. fluorescens WH6 & None & 10 \\
\hline
\end{tabular}


Table S3. 10-AA code of PvfC homologs. The number is listed for the pvf-containing bacterial strains with the respective 10-AA code.

\begin{tabular}{|c|c|c|c|c|c|c|c|c|c|c|c|}
\hline $\begin{array}{l}\text { Code } \\
\#\end{array}$ & $10-$ & $\mathrm{Ac}$ & & & & & & & & $\begin{array}{l}\text { Strains or constructs } \\
\text { mentioned in this study }\end{array}$ & $\begin{array}{l}\text { Number of } \\
\text { strains with code }\end{array}$ \\
\hline 1 & $\mathrm{D}$ & A & $\mathrm{L}$ & $\mathrm{F}$ & $\mathrm{V}$ & G & 11 & $\mathrm{~V}$ & L $K$ & L48/J2315/HI2424/H111 & 35 \\
\hline 2 & D & A & M & $\mathrm{F}$ & $\mathrm{L}$ & G & L & 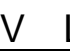 & L $K$ & & 10 \\
\hline 3 & D & $\mathrm{S}$ & $\mathrm{I}$ & $\mathrm{F}$ & C & G & L $\quad l$ & $\mathrm{~V} \quad \mathrm{I}$ & L $K$ & Pf0-1-M429C & 1 \\
\hline 4 & D & $\mathrm{S}$ & I & $\mathrm{F}$ & I & G & L & 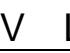 & L $K$ & Pf0-1-M429I & 1 \\
\hline 5 & $\mathrm{D}$ & $\mathrm{s}$ & 1 & $\mathrm{~F}$ & $\mathrm{~L}$ & G & L $\quad$ & $\mathrm{V} \mathrm{I}$ & L K & WH6 & 27 \\
\hline 6 & $\mathrm{D}$ & $\mathrm{S}$ & I & $\mathrm{F}$ & $\mathrm{M}$ & G & $\mathrm{L} \quad \mathrm{I}$ & $\mathrm{V} \mathrm{l}$ & $\mathrm{L} K$ & Pf0-1/DC3000/UMAF0158 & 174 \\
\hline 7 & $\mathrm{D}$ & $\mathrm{s}$ & I & $\mathrm{F}$ & $\bar{T}$ & G & $\mathrm{L} \quad \mathrm{I}$ & $\mathrm{V}$ & $\mathrm{L} K$ & Pf0-1-M429T & 3 \\
\hline 8 & $\mathrm{D}$ & $S$ & 1 & $\mathrm{~F}$ & V & $G$ & L $\quad$ & $\mathrm{V} \quad \mathrm{I}$ & L K & Pf0-1-M429V & 14 \\
\hline 9 & $\mathrm{D}$ & $\mathrm{S}$ & V & $\mathrm{F}$ & $\mathrm{L}$ & $G$ & L I & $\mathrm{V} \quad \mathrm{I}$ & $\mathrm{L} K$ & & 1 \\
\hline 10 & $D$ & $\mathrm{~V}$ & $\mathrm{~L}$ & $\mathrm{~F}$ & $\mathrm{~L}$ & $G$ & 11 & $\mathrm{~V} \quad \mathrm{I}$ & $\mathrm{LK}$ & & 8 \\
\hline 11 & $D$ & $\mathrm{~S}$ & I & $\mathrm{F}$ & $M$ & $G$ & $\mathrm{~F}$ & $\mathrm{~V} \quad \mathrm{I}$ & $\mathrm{L} K$ & & 2 \\
\hline 12 & $\mathrm{D}$ & $\mathrm{s}$ & 1 & $\mathrm{~F}$ & $\mathrm{~L}$ & $G$ & $\mathrm{FI}$ & $\mathrm{V} \quad \mathrm{I}$ & $\mathrm{L}$ & & 1 \\
\hline 13 & $\mathrm{D}$ & A & $\mathrm{L}$ & $\mathrm{F}$ & $\mathrm{I}$ & G & 11 & 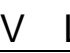 & L $K$ & L48-V444I & 30 \\
\hline 14 & $\mathrm{D}$ & $\mathrm{V}$ & $\mathrm{L}$ & $\mathrm{F}$ & $\mathrm{L}$ & $G$ & 11 & $\mathrm{~V}$ & $\mathrm{~F} \quad \mathrm{~K}$ & & 1 \\
\hline
\end{tabular}

Table S4. Number of amino acids different between each 10-AA code.

\begin{tabular}{|c|c|c|c|c|c|c|c|c|c|c|c|c|c|c|}
\hline Code \# & $\# 1$ & \#2 & \#3 & \#4 & $\# 5$ & \#6 & $\# 7$ & \#8 & $\# 9$ & $\# 10$ & \#11 & $\# 12$ & $\# 13$ & $\# 14$ \\
\hline$\# 1$ & & 3 & 4 & 4 & 4 & 4 & 4 & 3 & 4 & 2 & 4 & 4 & 1 & 3 \\
\hline \#2 & 3 & & 3 & 3 & 2 & 3 & 3 & 3 & 2 & 3 & 4 & 3 & 4 & 4 \\
\hline \#3 & 4 & 3 & & 1 & 1 & 1 & 1 & 1 & 2 & 4 & 2 & 2 & 4 & 5 \\
\hline \#4 & 4 & 3 & 1 & & 1 & 1 & 1 & 1 & 2 & 4 & 2 & 2 & 3 & 5 \\
\hline \#5 & 4 & 2 & 1 & 1 & & 1 & 1 & 1 & 1 & 3 & 2 & 1 & 4 & 4 \\
\hline \#6 & 4 & 3 & 1 & 1 & 1 & & 1 & 1 & 2 & 4 & 1 & 2 & 4 & 5 \\
\hline \#7 & 4 & 3 & 1 & 1 & 1 & 1 & & 1 & 2 & 4 & 2 & 2 & 4 & 5 \\
\hline \#8 & 3 & 3 & 1 & 1 & 1 & 1 & 1 & & 2 & 4 & 2 & 2 & 4 & 5 \\
\hline \#9 & 4 & 2 & 2 & 2 & 1 & 2 & 2 & 2 & & 3 & 3 & 2 & 4 & 4 \\
\hline$\# 10$ & 2 & 3 & 4 & 4 & 3 & 4 & 4 & 4 & 3 & & 5 & 4 & 3 & 1 \\
\hline$\# 11$ & 4 & 4 & 2 & 2 & 2 & 1 & 2 & 2 & 3 & 5 & & 1 & 4 & 5 \\
\hline$\# 12$ & 4 & 3 & 2 & 2 & 1 & 2 & 2 & 2 & 2 & 4 & 1 & & 4 & 4 \\
\hline$\# 13$ & 1 & 4 & 4 & 3 & 4 & 4 & 4 & 4 & 4 & 3 & 4 & 4 & & 3 \\
\hline$\# 14$ & 3 & 4 & 5 & 5 & 4 & 5 & 5 & 5 & 4 & 1 & 5 & 4 & 3 & \\
\hline
\end{tabular}


Table S5. Initial rates of $\mathrm{PvfC}_{\mathrm{L} 48}-\mathrm{SIML}$ and $\mathrm{PvfC}_{\mathrm{Pf0}-1}-\mathrm{ALVI}$ mutants.

\begin{tabular}{|c|c|c|c|}
\hline Construct & Substrate & $\begin{array}{l}\text { Initial rate with } 5 \mathrm{mM} \\
\text { substrate }\left(\mathrm{s}^{-1}\right)\end{array}$ & $\begin{array}{l}\text { Initial rate with } 10 \mathrm{mM} \\
\text { substrate }\left(\mathrm{s}^{-1}\right)\end{array}$ \\
\hline \multirow[t]{2}{*}{$\mathrm{PvfC}_{\mathrm{Pf0}-1}-\mathrm{ALVI}$} & L-Leu & $0.95 \pm 0.3$ & $1.13 \pm 0.06$ \\
\hline & L-Val & N/A & $\mathrm{N} / \mathrm{A}$ \\
\hline \multirow[t]{2}{*}{$\mathrm{PvfC}_{\mathrm{L} 48-\mathrm{SIML}}$} & L-Leu & $0.53 \pm 0.04$ & $0.90 \pm 0.02$ \\
\hline & L-Val & $0.08 \pm 0.01$ & $0.09 \pm 0.01$ \\
\hline
\end{tabular}

Table S6. Accession IDs of proteins used in this study

\begin{tabular}{|l|l|l|}
\hline Protein & UniProt Accession ID & NCBI Accession ID \\
\hline PvfC $_{\llcorner 48}$ & Q1IGU3 & CAK13109 \\
\hline PvfC $_{\mathrm{Pf0}-1}$ & Q3KK36 & ABA71870 \\
\hline PvfC $_{\mathrm{WH} 6}$ & E2XJF6 & EFQ66044 \\
\hline
\end{tabular}



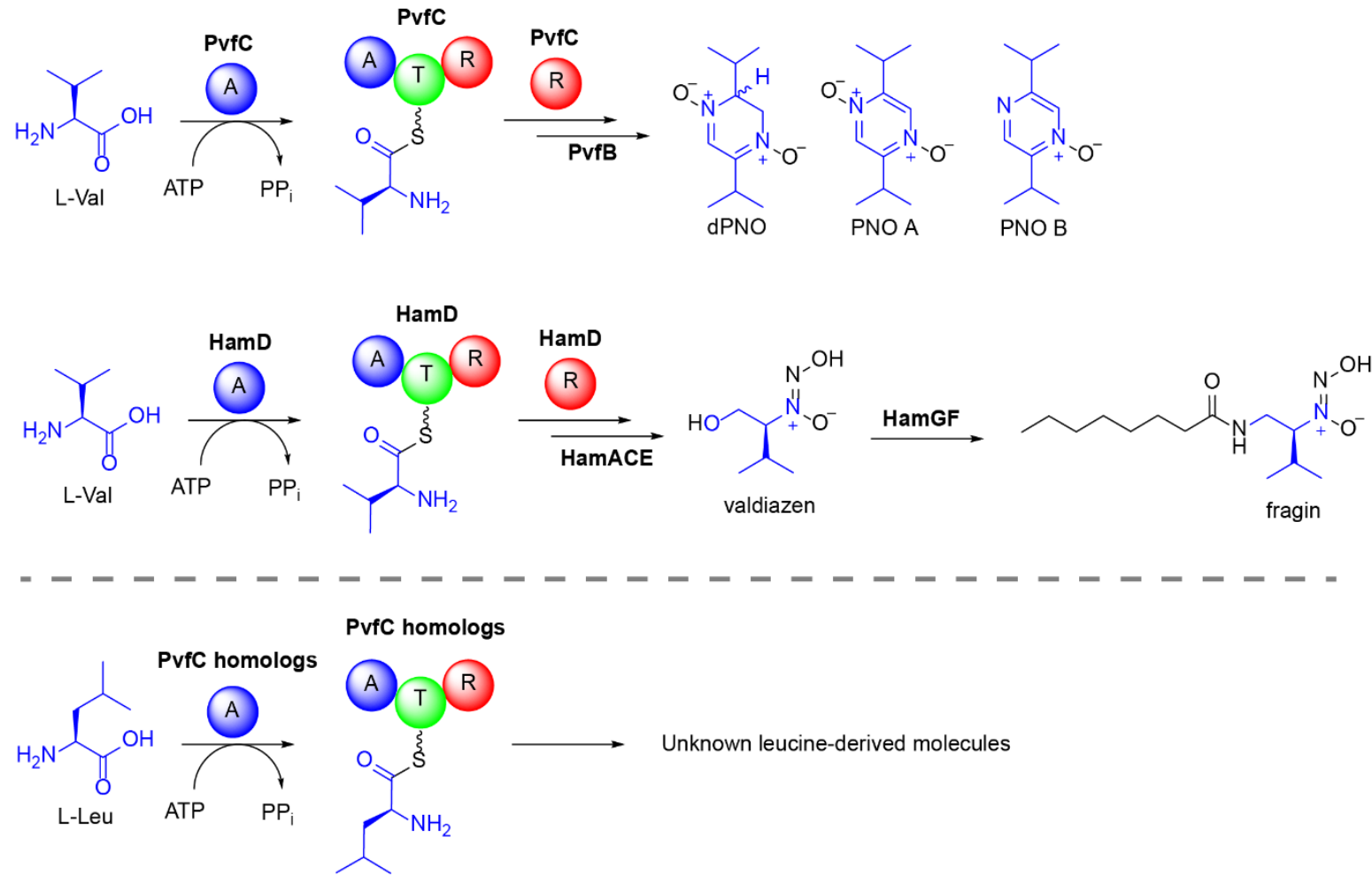

Figure S1. Incorporation of amino acids into small molecules produced by pvf-encoded enzymes. PvfC in $P$. entomophila $L 48$ incorporates $L-V a l$ into (dihydro)pyrazine $N$-oxides dPNO, PNO A, and PNO B. ${ }^{11} \mathrm{HamD}$, the PvfC homolog from B. cenocepacia $\mathrm{H} 111$, was proposed to incorporate $\mathrm{L}-\mathrm{V}$ al into valdiazen and fragin. ${ }^{12}$ The genes hamABCDE are homologous to pvfAEBCD, respectively ( $h a m G$ is an aminotransferase and hamF is a starter condensation domain, both of which are absent in P. entomophila L48). In this study, we show that PvfC homologs activate L-Leu and incorporate it into signaling molecules whose structures remain to be identified. 


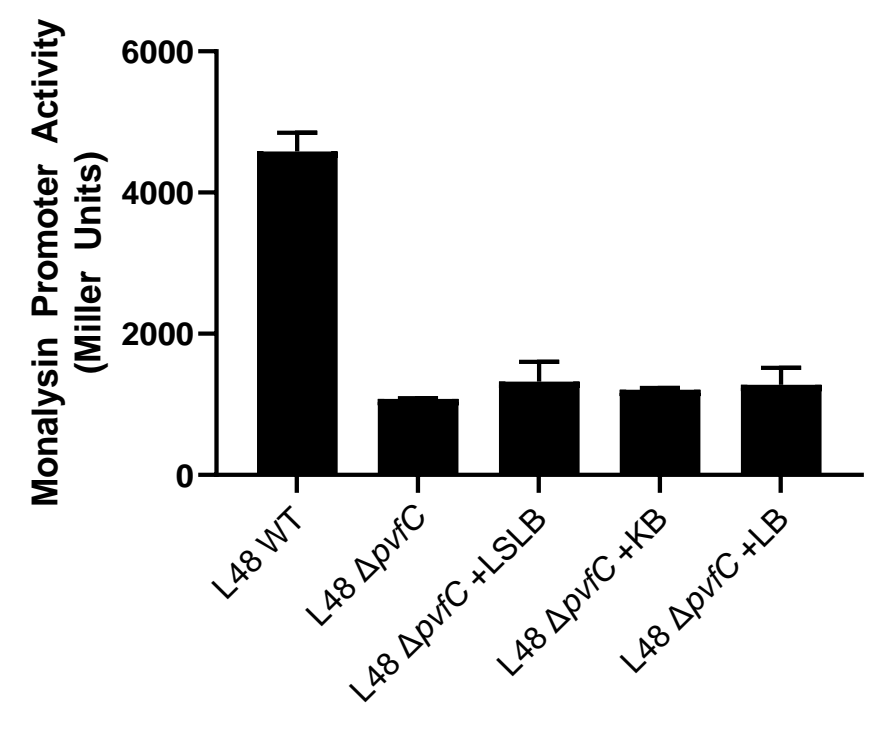

Figure S2. Fresh media control does not complement L48 $\Delta p v f C:: P_{m n r} l a c Z$. In the main text Figure 1B, P. entomophila L48 and B. cenocepacia HI2424 were grown in Lennox Broth (LSLB). P. syringae pv. tomato DC000 was grown in King's Medium B (KB). P. fluorescens Pf01 and WH6 were grown in Luria Broth (LB). WT (positive control) represents activity of P. entomophila $L 48:: \mathrm{P}_{m n}-l a c Z$. $\triangle p v f C$ (background) represents activity of $L 48 \Delta p v f C:: \mathrm{P}_{\mathrm{mn}}-$ lacZ. Supplementation of fresh media (LSLB, KB, LB) to P. entomophila L48 $\Delta p v f C:: \mathrm{P}_{m n l}$-lacZ used to grow pvf-containing strains does not complement actvitiy of $L 48 \Delta p v f C:: \mathrm{P}_{m n}-\mathrm{lac} Z$. 


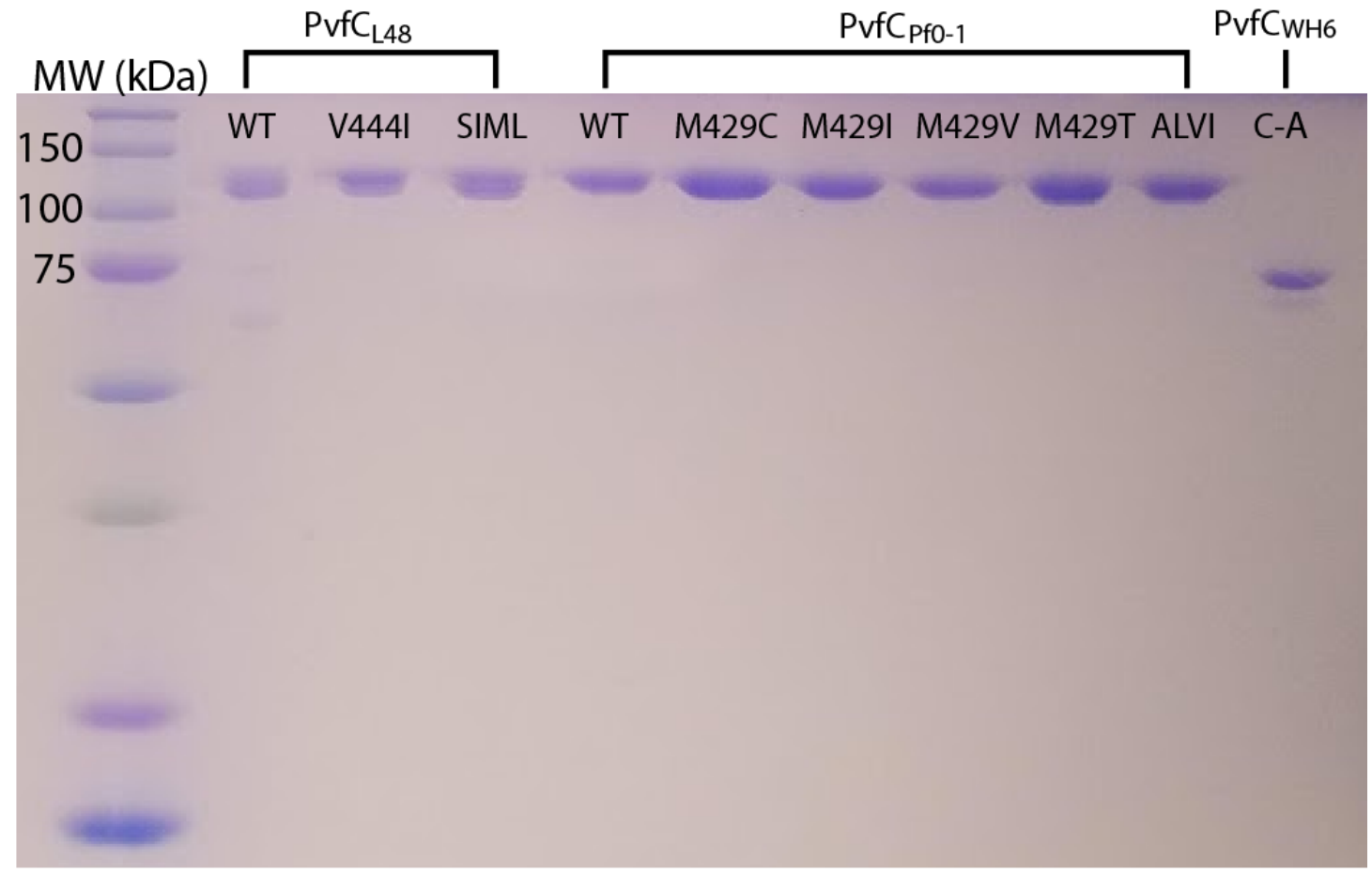

Figure S3. SDS-PAGE analyses of all proteins used in this study. Expected molecular weight: $P_{v f C} L_{48}$ and mutants=130 kDa, PvfC $C_{10-1}$ and mutants=129 kDa, PvfC-AwH6=76kDa. All calculated weights include 6xHis-tag.

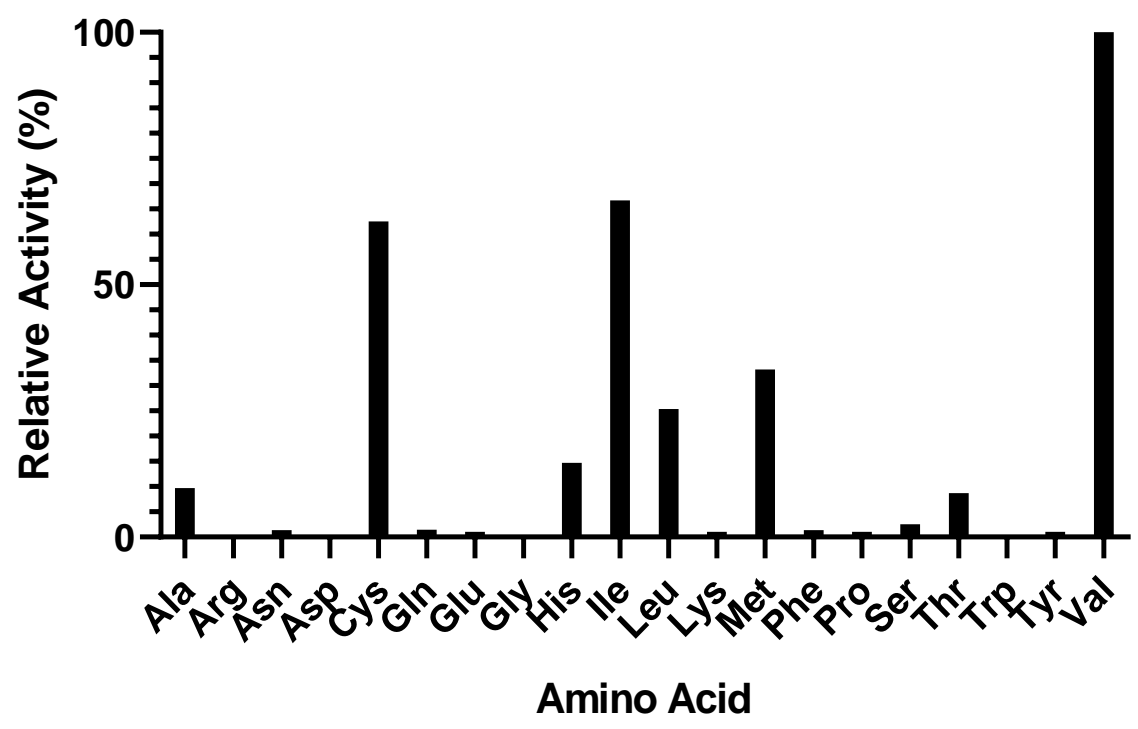

Figure S4. Activity of $\mathrm{PvfC}_{\mathrm{L48}}$ toward 20 amino acids as determined by an ATP-[ $\left.{ }^{32} \mathrm{P}\right] \mathrm{PP}_{\mathrm{i}}$ exchange end-point assay. Activity is relative to the activation of L-Val. 


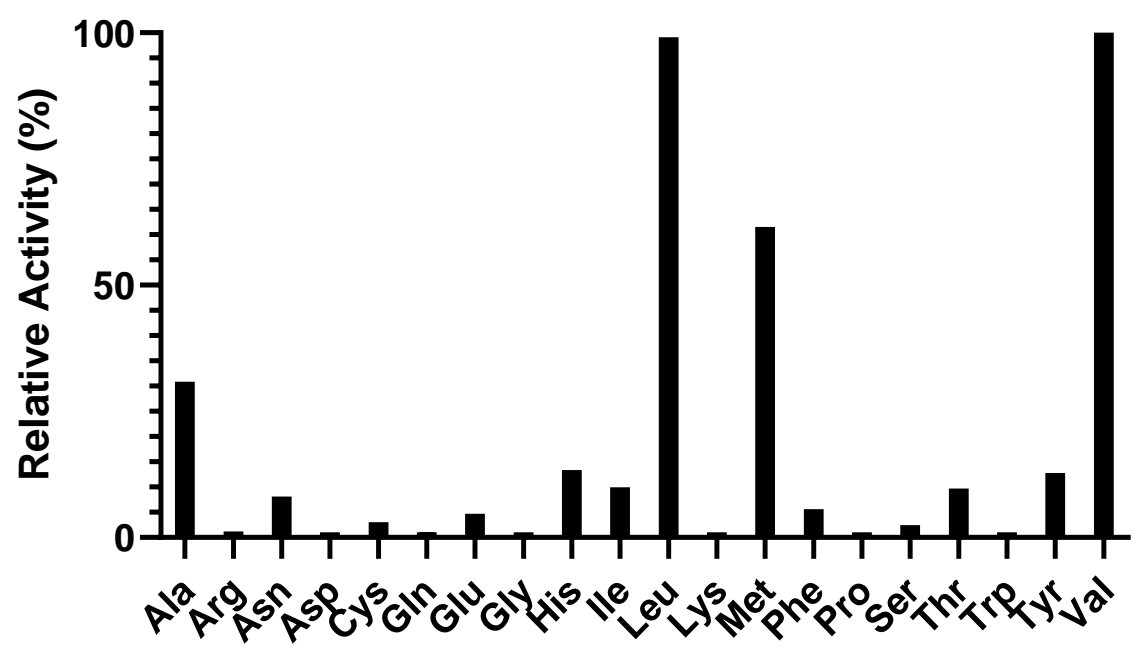

Amino Acid

Figure S5. Activity of $\mathrm{PvfC}_{\mathrm{Pf0}-1}$ toward 20 amino acids as determined by an ATP-[ $\left.{ }^{32} \mathrm{P}\right] \mathrm{PP}$ exchange end-point assay. Activity is relative to the activation of L-Val.
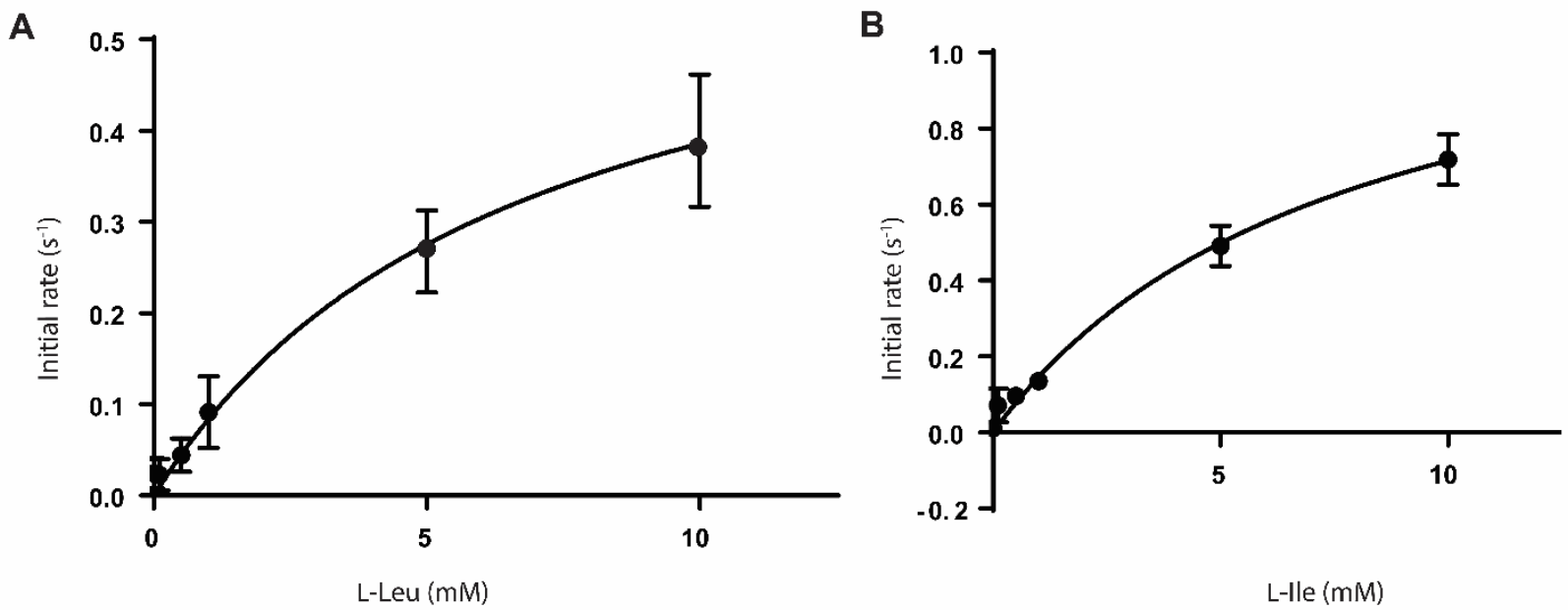

Figure S6. Steady-state kinetic analysis of $\mathrm{PvfC}_{\mathrm{L} 48}$ toward (A) L-Leu and (B) L-Ile determined by an ATP-[32P]PP exchange assay. L-Leu, $k_{\text {cat }}=0.65 \pm 0.1 \mathrm{~s}^{-1} K_{\mathrm{M}}=7 \pm 3 \mathrm{mM}$, $1 / K_{\mathrm{M}}=150 \pm 10 \mathrm{M}^{-1}, K_{\text {cat }} / K_{\mathrm{M}}=93 \mathrm{M}^{-1} \mathrm{~s}^{-1}$. L-Ile, $k_{\text {cat }}=1.3 \pm 0.2 \mathrm{~s}^{-1}, K_{\mathrm{M}}=8 \pm 2 \mathrm{mM}, 1 / K_{\mathrm{M}}=130 \pm 20$ $\mathrm{M}^{-1}, k_{\mathrm{cat}} / K_{\mathrm{M}}=160 \mathrm{M}^{-1} \mathrm{~s}^{-1}$. 


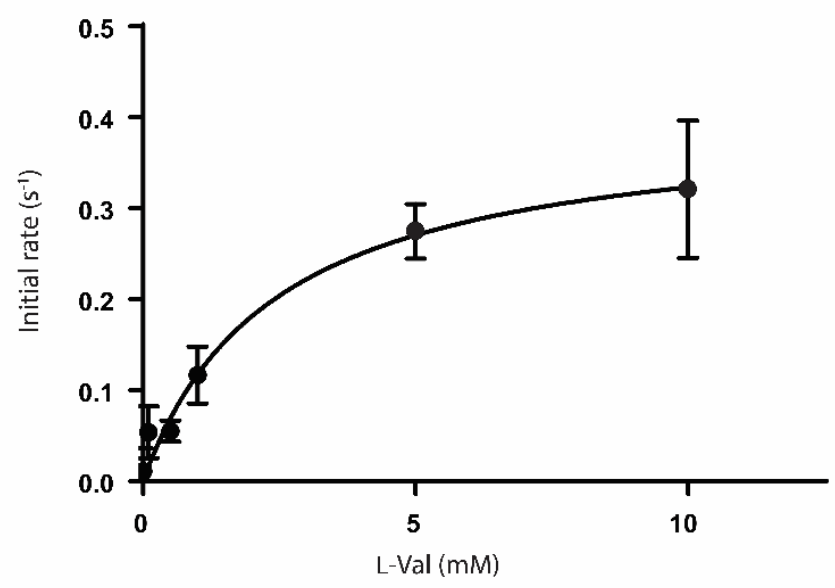

Figure S7. Steady-state kinetic analysis of $\mathrm{PvfC}_{\mathrm{Pt0}-1}$ toward L-Val determined by an ATP$\left.{ }^{32} \mathrm{P}\right] \mathrm{PP} \mathrm{P}_{\mathrm{i}}$ exchange assay. $\mathrm{L}-\mathrm{Val}, K_{\mathrm{cat}}=0.40 \pm 0.04 \mathrm{~s}^{-1}, K_{\mathrm{M}}=2.4 \pm 0.8 \mathrm{mM}, 1 / K_{\mathrm{M}}=430 \pm 70 \mathrm{M}^{-1}$, $k_{\text {cat }} / K_{\mathrm{M}}=170 \mathrm{M}^{-1} \mathrm{~s}^{-1}$.

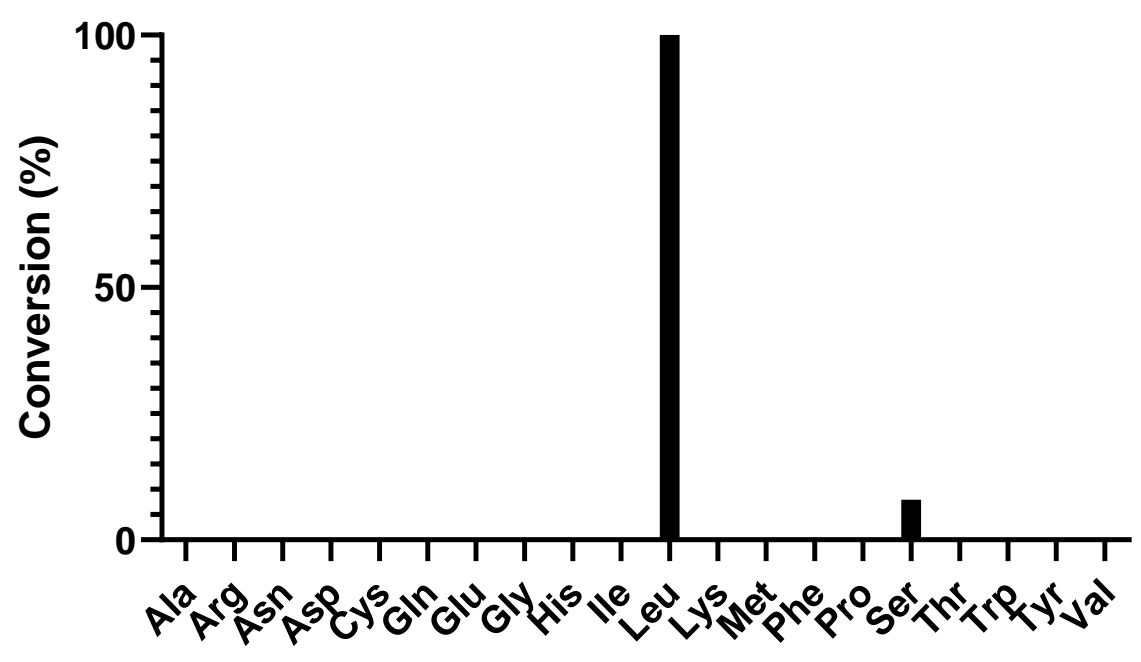

Amino Acid

Figure S8. Activity of PvfC-AwH6 toward 20 amino acids determined by an ATP-[32P]PP exchange end-point assay. Activity is relative to the activation of L-Leu. 


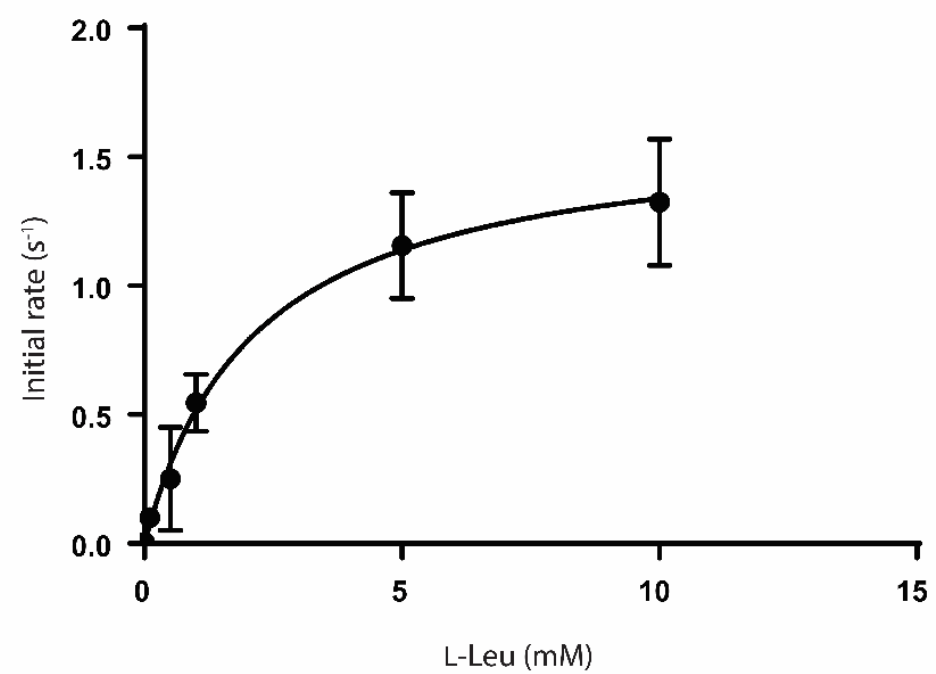

Figure S9. Steady-state kinetic analysis of PvfC-AwH6 toward L-Leu determined by an ATP-[ $\left.{ }^{32} \mathrm{P}\right] P P_{\mathrm{i}}$ exchange assay. L-Leu, $k_{\mathrm{cat}}=1.6 \pm 0.1 \mathrm{~s}^{-1}, K_{\mathrm{M}}=2.1 \pm 0.6 \mathrm{mM}, 1 / K_{\mathrm{M}}=560 \pm 80$ $\mathrm{M}^{-1}, k_{\text {cat }} / K_{\mathrm{M}}=760 \mathrm{M}^{-1} \mathrm{~s}^{-1}$.

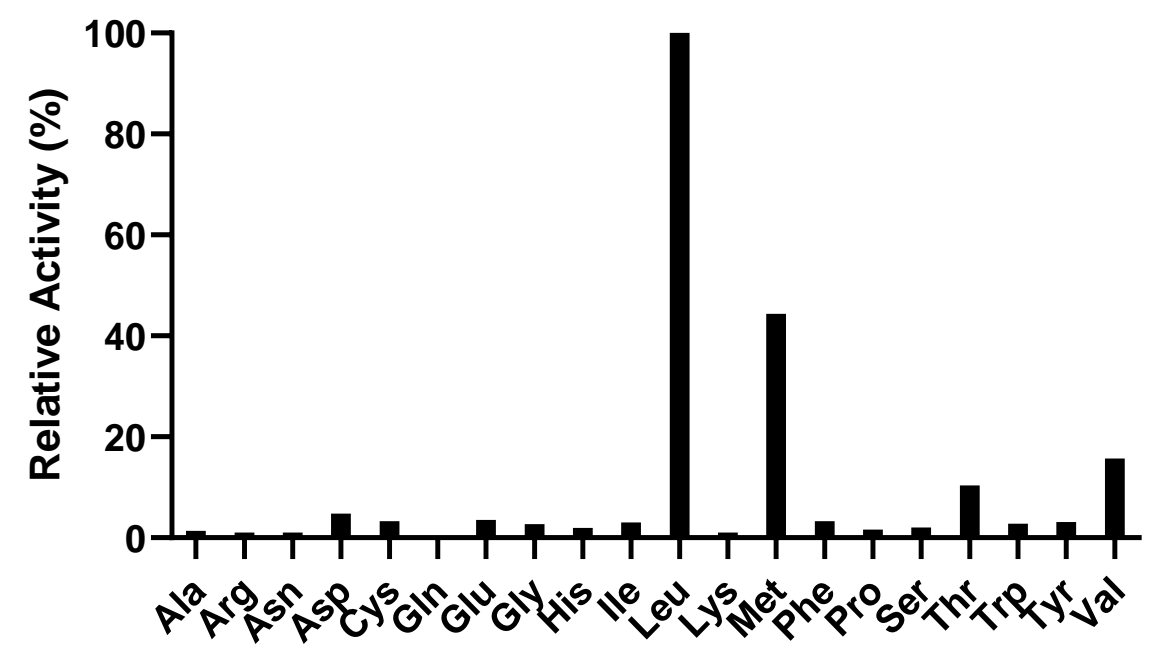

Amino Acid

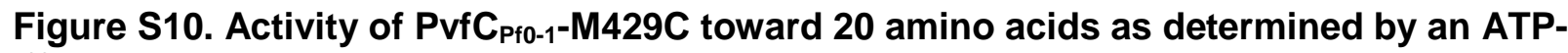
$\left.{ }^{32} \mathrm{P}\right] P P_{i}$ exchange end-point assay. Activity is relative to the activation of L-Leu. 

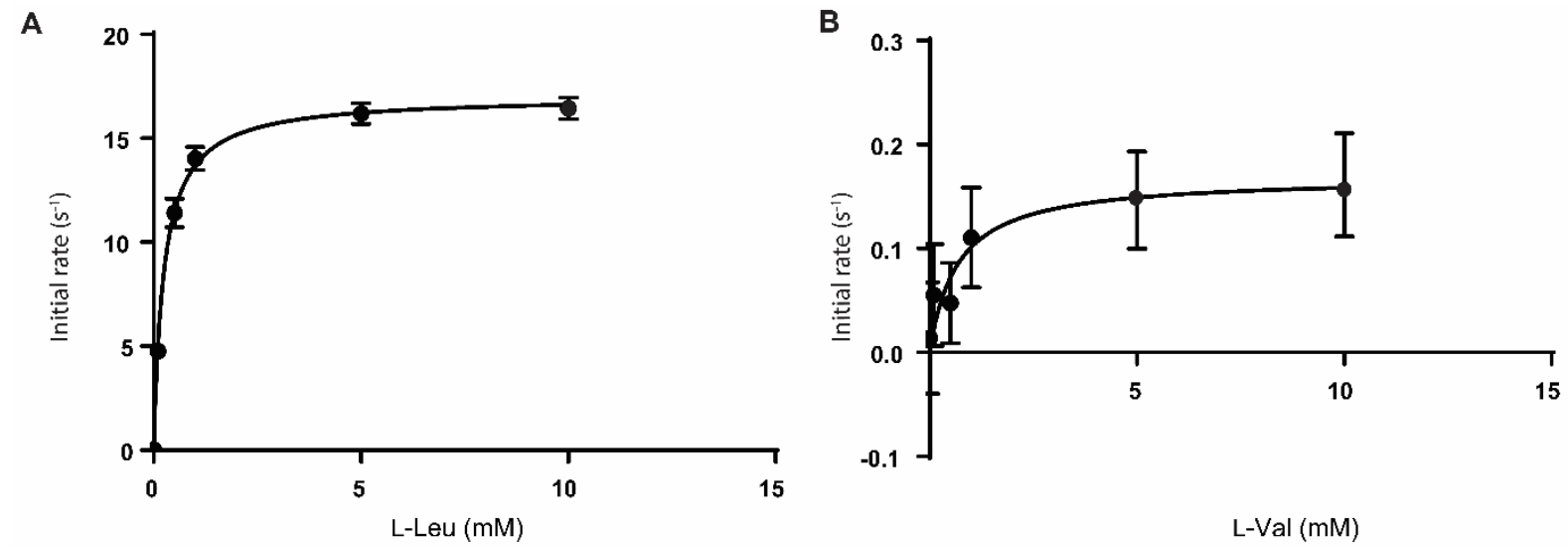

Figure S11. Steady-state kinetic analysis of $\mathrm{PvfC}_{\mathrm{Pf0}-1}-\mathrm{M} 429 \mathrm{C}$ toward (A) L-Leu and (B) LVal determined by an ATP-[ $\left.{ }^{32} P\right] P P_{i}$ exchange assay. L-Leu, $k_{\text {cat }}=17.0 \pm 0.2 \mathrm{~s}^{-1}, K_{\mathrm{M}}=0.24 \pm$ $0.01 \mathrm{mM}, 1 / K_{\mathrm{M}}=4100 \pm 100 \mathrm{M}^{-1}, k_{\text {cat }} / K_{\mathrm{M}}=7.1 \times 10^{4} \mathrm{M}^{-1} \mathrm{~s}^{-1}$. L-Val, $K_{\text {cat }}=0.17 \pm 0.03 \mathrm{~s}^{-1}, K_{\mathrm{M}}=0.6 \pm$ $0.4 \mathrm{mM}, 1 / K_{\mathrm{M}}=3100 \pm 2400 \mathrm{M}^{-1}, K_{\text {cat }} / K_{\mathrm{M}}=280 \mathrm{M}^{-1} \mathrm{~s}^{-1}$

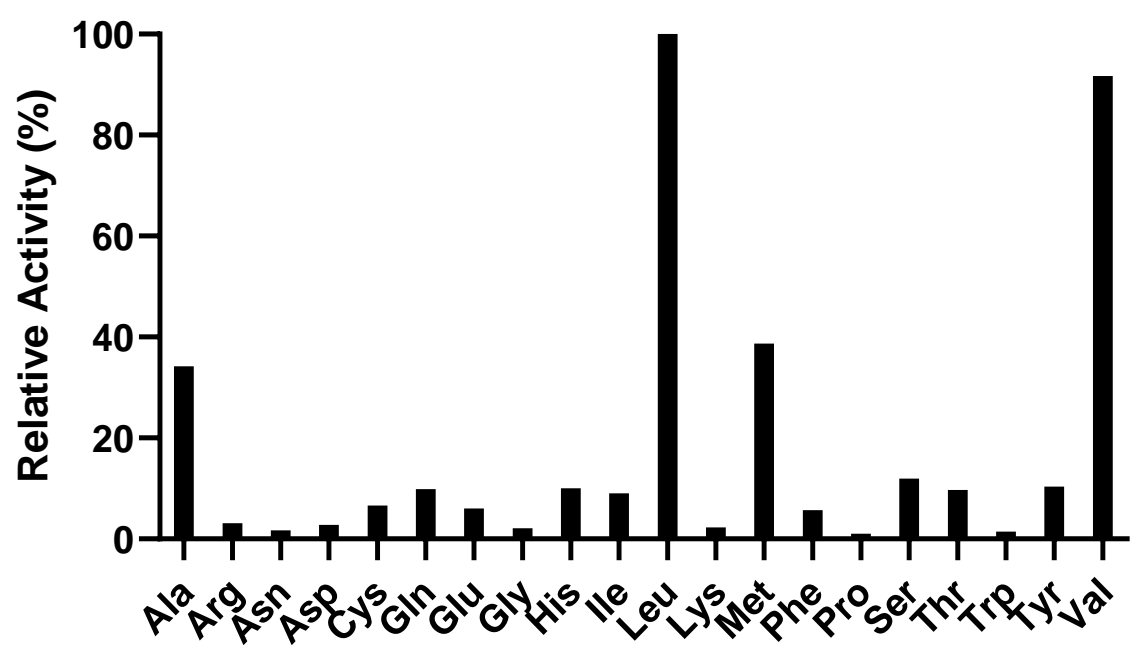

Amino Acid

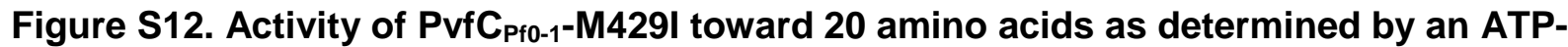
$\left[{ }^{32} \mathrm{P}\right] \mathrm{PP} \mathrm{P}_{\mathrm{i}}$ exchange end-point assay. Activity is relative to the activation of L-Leu. 


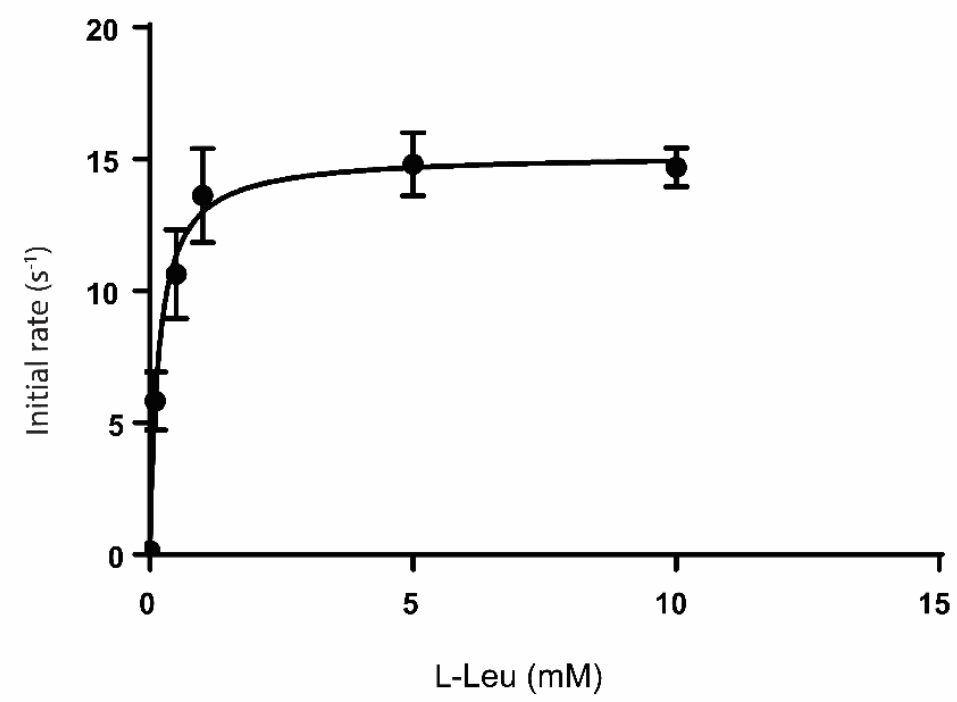

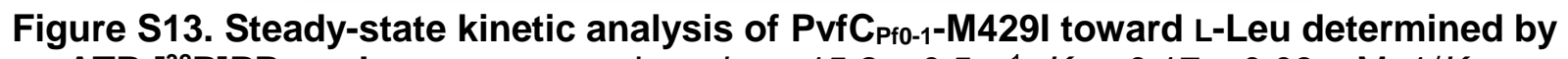
an ATP-[ $\left.{ }^{32} \mathrm{P}\right] P P_{\mathrm{i}}$ exchange assay. L-Leu, $K_{\mathrm{cat}}=15.2 \pm 0.5 \mathrm{~s}^{-1}, K_{\mathrm{M}}=0.17 \pm 0.03 \mathrm{mM}, 1 / K_{\mathrm{M}}=$ $6100 \pm 1400 \mathrm{M}^{-1}, K_{\mathrm{cat}} / K_{\mathrm{M}}=8.9 \times 10^{4} \mathrm{M}^{-1} \mathrm{~s}^{-1}$. No activity was observed in the steady-state kinetic analysis of $\mathrm{PvfC}_{\mathrm{Pf0}-1}-\mathrm{M} 429 \mathrm{I}$ toward L-Val.

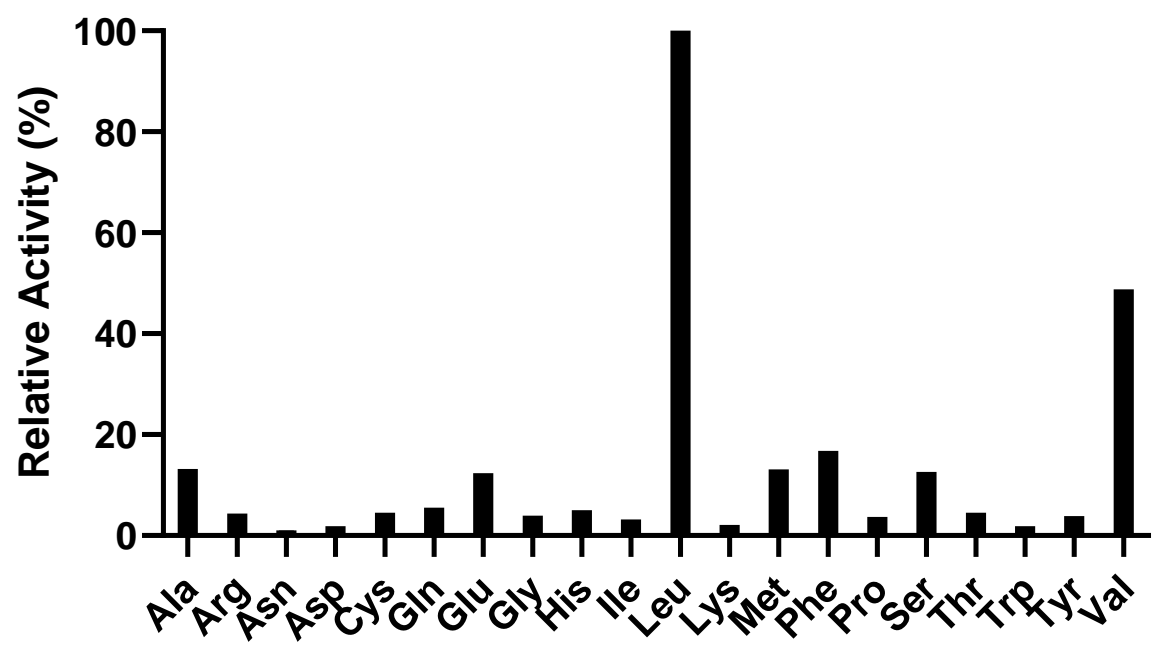

Amino Acid

Figure S14. Activity of PvfC $\mathrm{Pf0}_{-1}-\mathrm{M} 429 \mathrm{~T}$ toward 20 amino acids determined by an ATP$\left[{ }^{32} \mathrm{P}\right] \mathrm{PP}_{\mathrm{i}}$ exchange end-point assay. Activity is relative to the activation of L-Leu. 
A

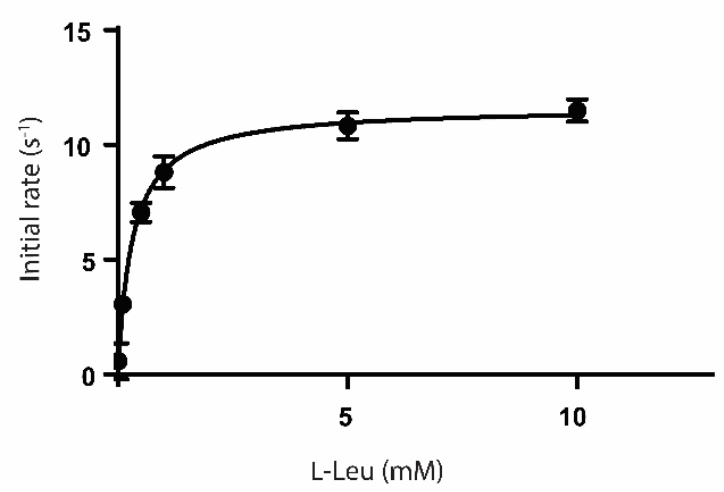

B

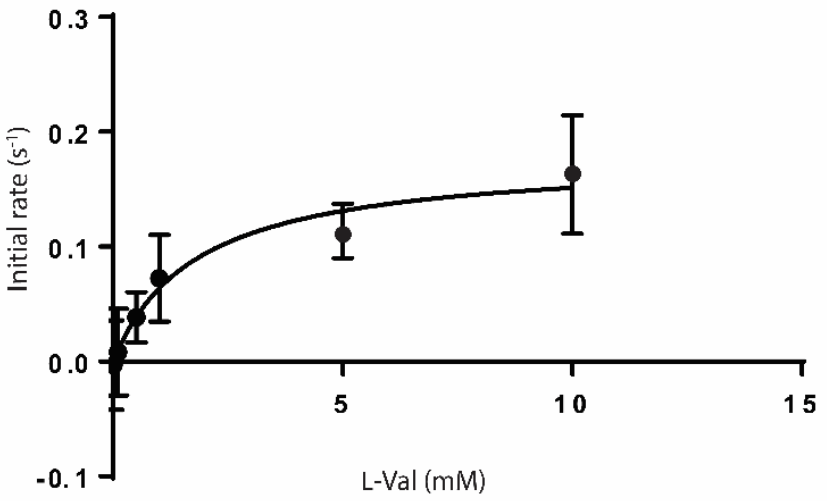

Figure S15. Steady-state kinetic analysis of PvfC $\mathrm{Pf0}_{\mathrm{P}-1}-\mathrm{M} 429 \mathrm{~T}$ toward (A) L-Leu and (B) L-Val as substrates determined by an ATP-[32P]PP $P_{i}$ exchange assay. L-Leu, $k_{\text {cat }}=11.6 \pm 0.3 \mathrm{~s}^{-1}$, $K_{\mathrm{M}}=0.31 \pm 0.03 \mathrm{mM}, 1 / K_{\mathrm{M}}=3200 \pm 270 \mathrm{M}^{-1}, K_{\mathrm{cat}} / K_{\mathrm{M}}=3.7 \times 10^{4} \mathrm{M}^{-1} \mathrm{~s}^{-1}$. L-Val, $K_{\text {cat }}=0.18 \pm 0.03 \mathrm{~s}$ $1, K_{\mathrm{M}}=2 \pm 1 \mathrm{mM}, 1 / K_{\mathrm{M}}=720 \pm 470 \mathrm{M}^{-1}, K_{\mathrm{cat}} / K_{\mathrm{M}}=90 \mathrm{M}^{-1} \mathrm{~s}^{-1}$.

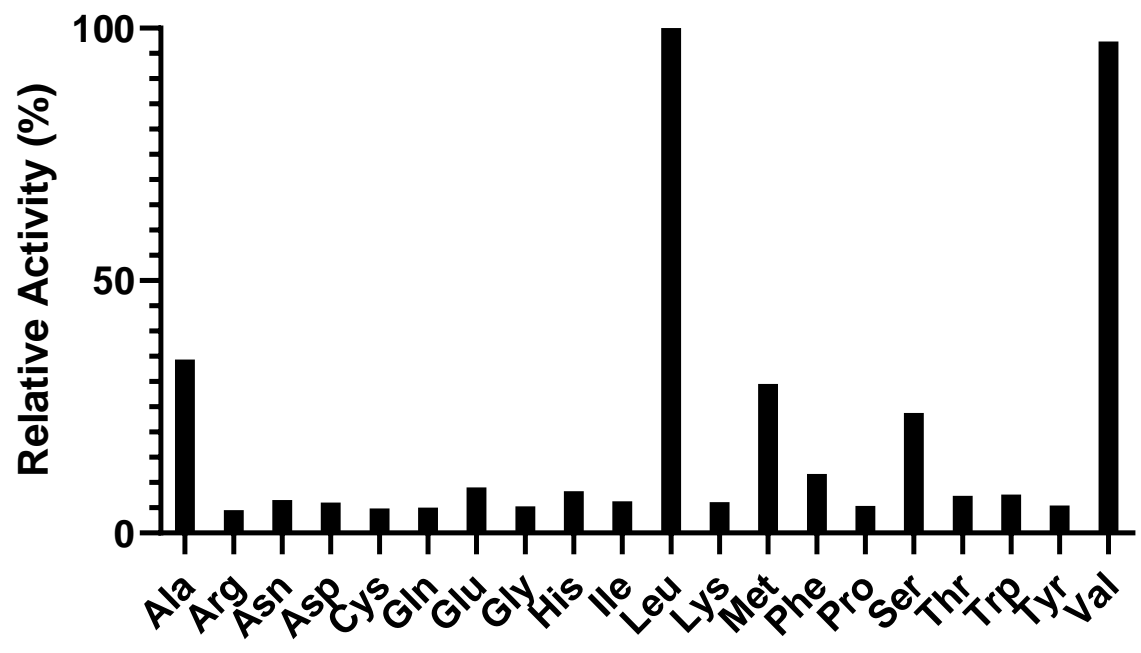

Amino Acid

Figure S16. Activity of PvfC $\mathrm{Pf0}_{-1}-\mathrm{M} 429 \mathrm{~V}$ toward 20 amino acids determined by an ATP$\left[{ }^{32} \mathrm{P}\right] \mathrm{PP}_{\mathrm{i}}$ exchange end-point assay. Activity is relative to the activation of L-Leu. 


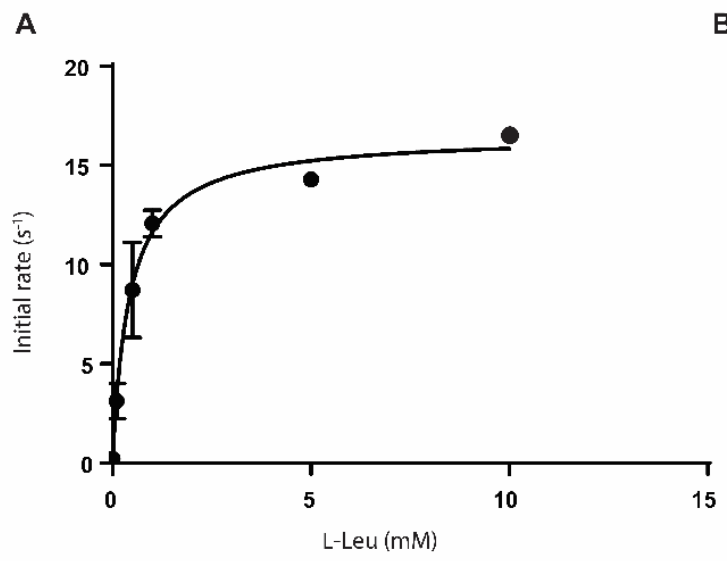

B

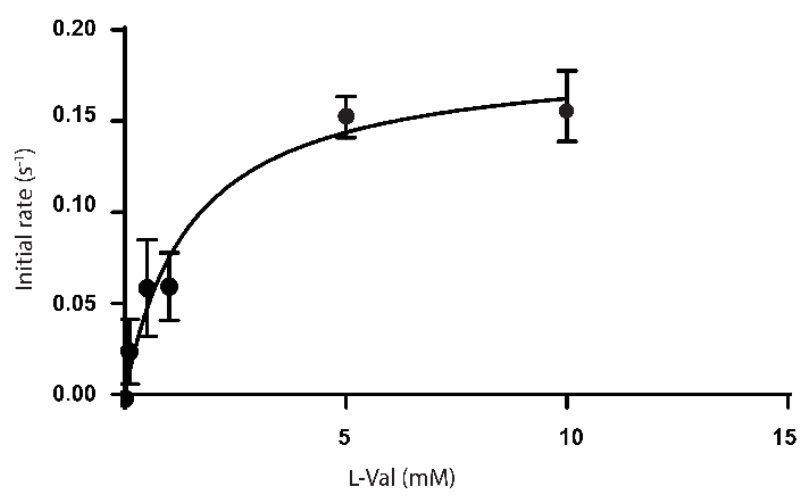

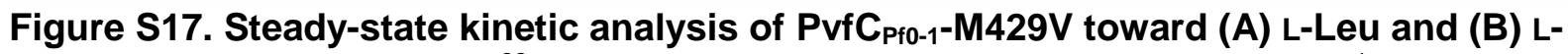
Val determined by an ATP-[ $\left.{ }^{32} P\right] P P_{i}$ exchange assay. L-Leu, $k_{\text {cat }}=16.5 \pm 0.6 \mathrm{~s}^{-1}, K_{\mathrm{M}}=0.42 \pm$ $0.06 \mathrm{mM}, 1 / K_{\mathrm{M}}=2500 \pm 640 \mathrm{M}^{-1}, k_{\text {cat }} / K_{\mathrm{M}}=3.9 \times 10^{4} \mathrm{M}^{-1} \mathrm{~s}^{-1}$. L-Val, $k_{\text {cat }}=0.19 \pm 0.02 \mathrm{~s}^{-1}, K_{\mathrm{M}}=1.5 \pm$ $0.4 \mathrm{mM}, 1 / K_{\mathrm{M}}=690 \pm 70 \mathrm{M}^{-1}, k_{\text {cat }} / K_{\mathrm{M}}=130 \mathrm{M}^{-1} \mathrm{~s}^{-1}$.

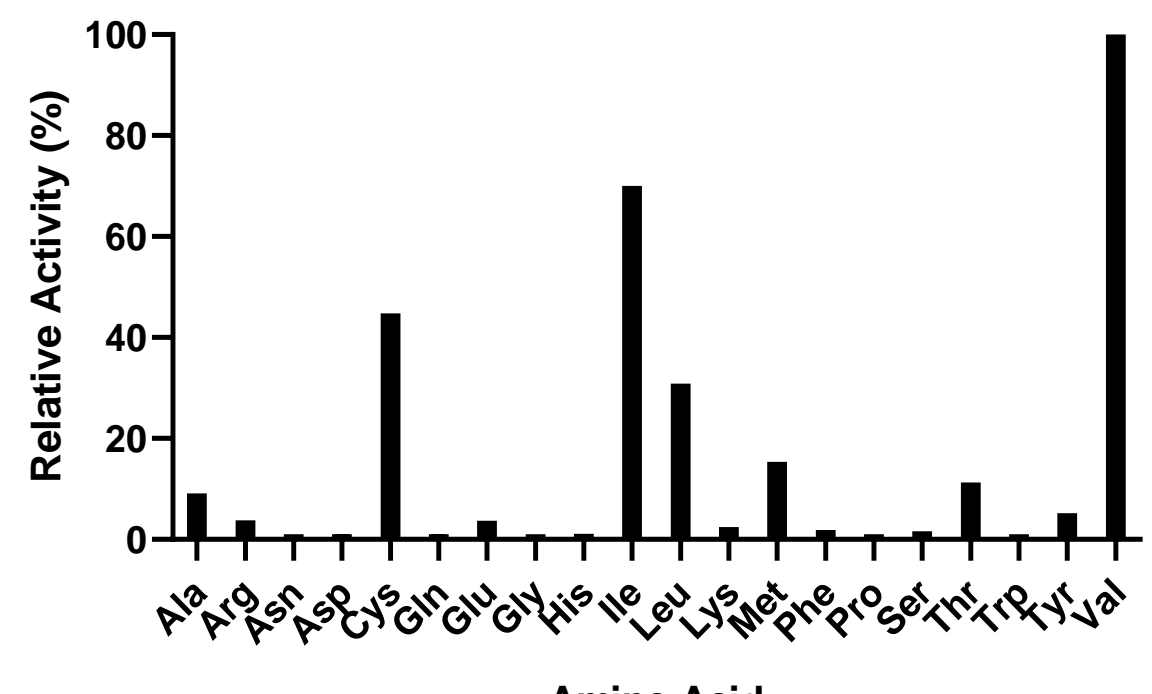

Amino Acid

Figure S18. Activity of $\mathrm{PvfC}_{\mathrm{L} 48}$-V444I toward 20 amino acids determined by an ATP$\left[{ }^{32} \mathrm{P}\right] \mathrm{PP} \mathrm{P}_{\mathrm{i}}$ exchange end-point assay. Activity is relative to the activation of $\mathrm{L}-\mathrm{V}$ al. 
A

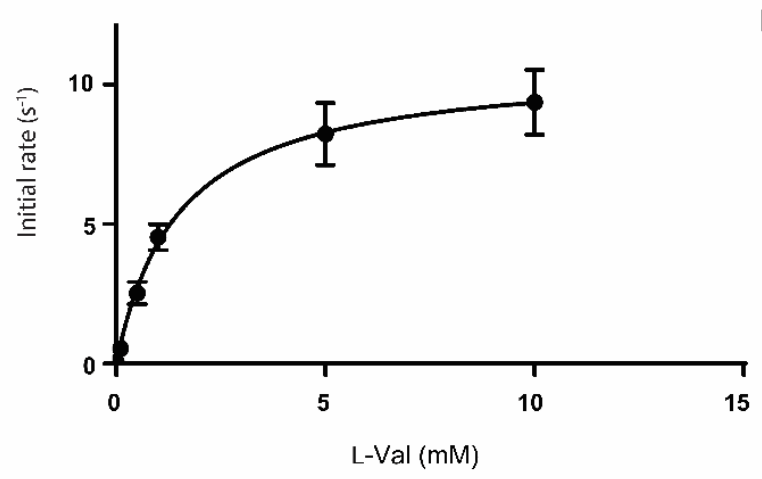

C

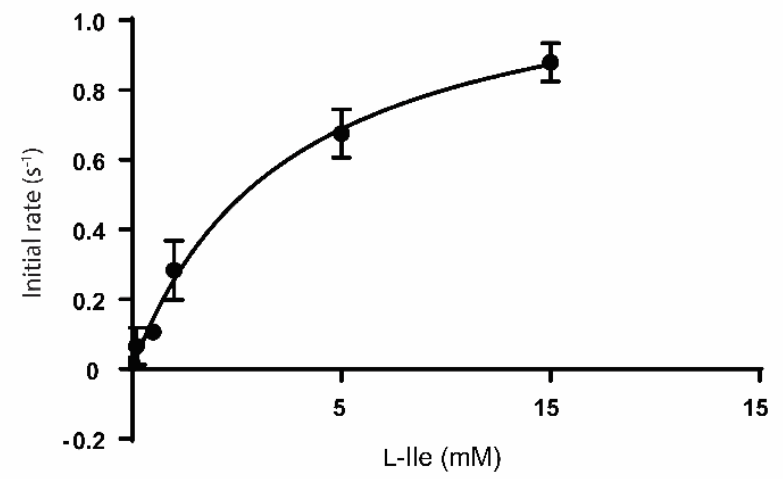

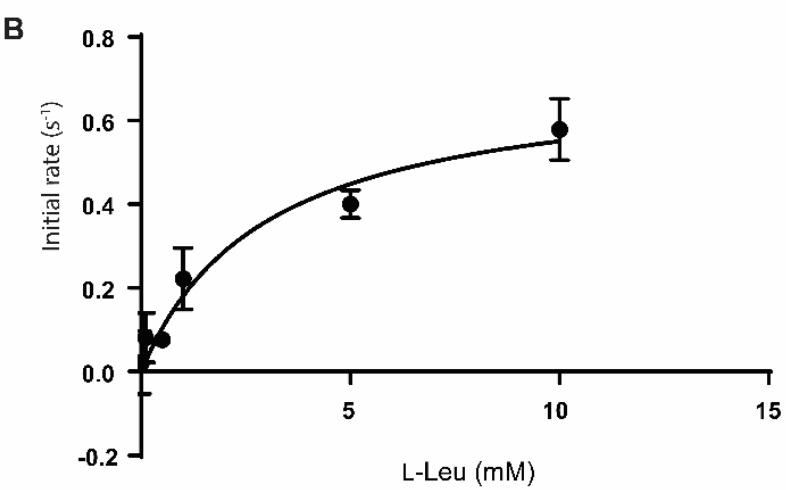

Figure S19. Steady-state kinetic analysis of $\mathrm{PvfC}_{\mathrm{L} 48^{-}} \mathrm{V} 444 \mathrm{I}$ toward $\left.(\mathrm{A}) \mathrm{L}-\mathrm{Val}, \mathrm{B}\right) \mathrm{L}-\mathrm{Leu}$, and (C) L-Ile determined by an ATP-[ $\left.{ }^{32} P\right] P P_{i}$ exchange assay. L-Val, $K_{\text {cat }}=10.7 \pm 0.5 \mathrm{~s}^{-1}, K_{\mathrm{M}}=1.5$ $\pm 0.2 \mathrm{mM}, 1 / K_{\mathrm{M}}=670 \pm 30 \mathrm{M}^{-1}, K_{\text {cat }} / K_{\mathrm{M}}=7.1 \times 10^{3} \mathrm{M}^{-1} \mathrm{~s}^{-1}$. L-Leu, $K_{\text {cat }}=0.71 \pm 0.09 \mathrm{~s}^{-1}, K_{\mathrm{M}}=3 \pm 1$ $\mathrm{mM}, 1 / K_{\mathrm{M}}=410 \pm 150 \mathrm{M}^{-1}, k_{\mathrm{cat}} / K_{\mathrm{M}}=240 \mathrm{M}^{-1} \mathrm{~s}^{-1}$. L-lle, $k_{\text {cat }}=1.2 \pm 0.09 \mathrm{~s}^{-1}, K_{\mathrm{M}}=3.7 \pm 0.7 \mathrm{mM}$, $1 / K_{M}=280 \pm 110 \mathrm{M}^{-1}, K_{\mathrm{cat}} / K_{\mathrm{M}}=320 \mathrm{M}^{-1} \mathrm{~s}^{-1}$. 
A

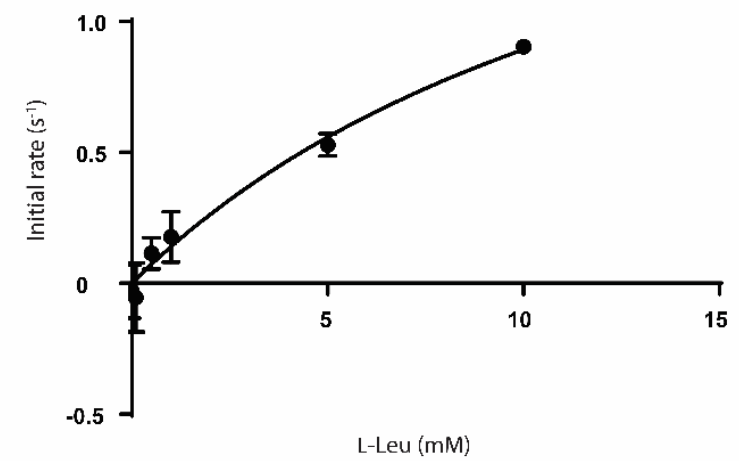

B

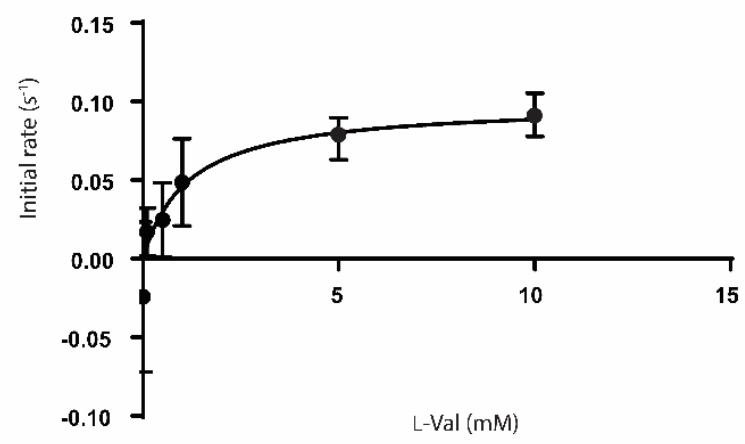

Figure S20. Steady-state kinetic analysis of $\mathrm{PvfC}_{\mathrm{L} 48}$-A381S, L384I, V444M, I467L (SIML) toward (A) L-Leu and (B) L-Val determined by an ATP-[ $\left.{ }^{32} \mathrm{P}\right] \mathrm{PP} \mathrm{P}_{\mathrm{i}}$ exchange assay. L-Leu, $k_{\mathrm{cat}}=$ $2.2 \pm 0.8 \mathrm{~s}^{-1}, K_{\mathrm{M}}=15 \pm 9 \mathrm{mM}, 1 / K_{\mathrm{M}}=210 \pm 100 \mathrm{M}^{-1}, K_{\text {cat }} / K_{\mathrm{M}}=150 \mathrm{M}^{-1} \mathrm{~s}^{-1}$. L-Val, $K_{\text {cat }}=0.03 \pm 0.01$ $\mathrm{s}^{-1}, K_{\mathrm{M}}=1.2 \pm 0.7 \mathrm{mM}, 1 / K_{\mathrm{M}}=1000 \pm 450 \mathrm{M}^{-1}, k_{\mathrm{cat}} / K_{\mathrm{M}}=25 \mathrm{M}^{-1} \mathrm{~s}^{-1}$. 


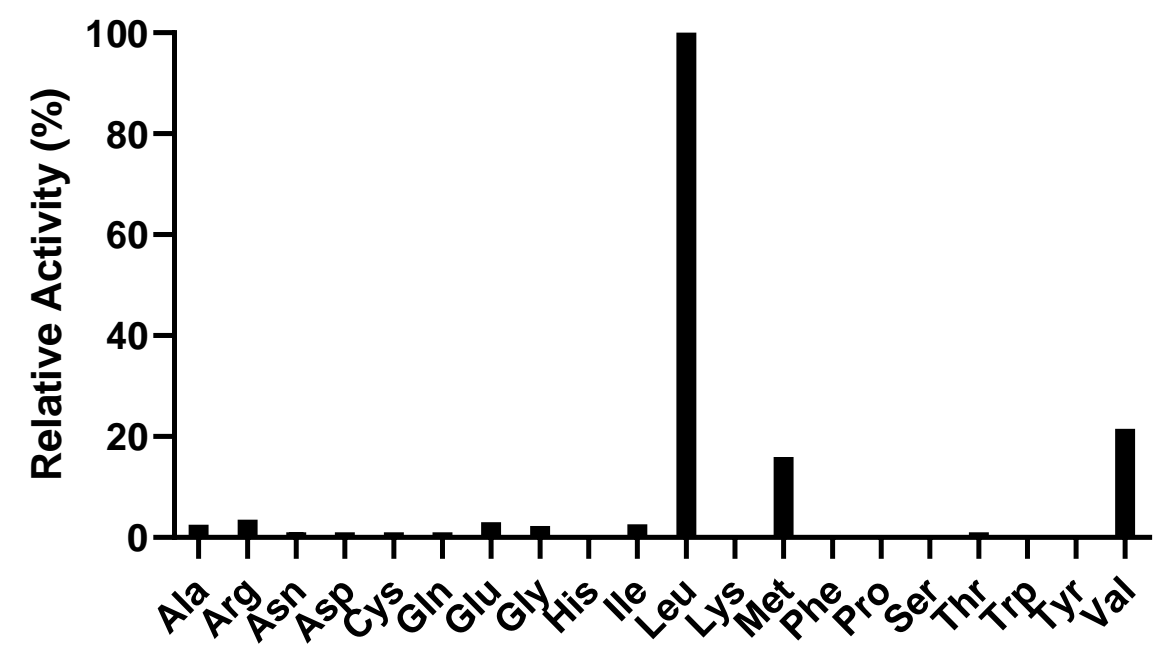

Amino Acid

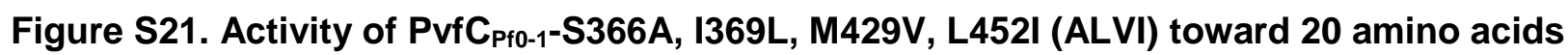
as determined by an ATP-[32P]PP $i$ exchange end-point assay. Activity is relative to the activation of L-Leu.

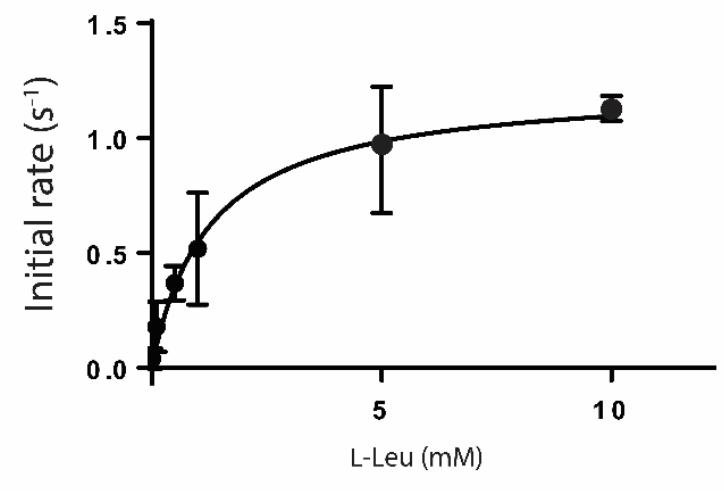

Figure S22. Steady-state kinetic analysis of PvfC $\mathrm{Pf0}_{-1}-\mathrm{S} 366 \mathrm{~A}$, I369L, M429V, L452I (ALVI) toward L-Leu determined by an ATP-[32P]PP exchange assay. L-Leu, $k_{\text {cat }}=1.2 \pm 0.1 \mathrm{~s}^{-1}, K_{\mathrm{M}}=$ $1.3 \pm 0.4 \mathrm{mM}, 1 / K_{\mathrm{M}}=860 \pm 290 \mathrm{M}^{-1}, K_{\mathrm{cat}} / K_{\mathrm{M}}=920 \mathrm{M}^{-1} \mathrm{~s}^{-1}$. No activity was observed in the steady-state kinetic analysis of PvfC ${ }_{\text {Pro-1 }}-\mathrm{ALVI}$ toward L-Val. 
A

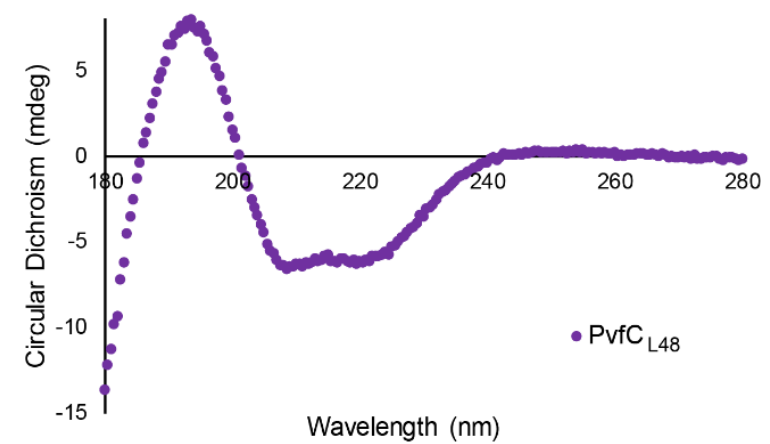

B

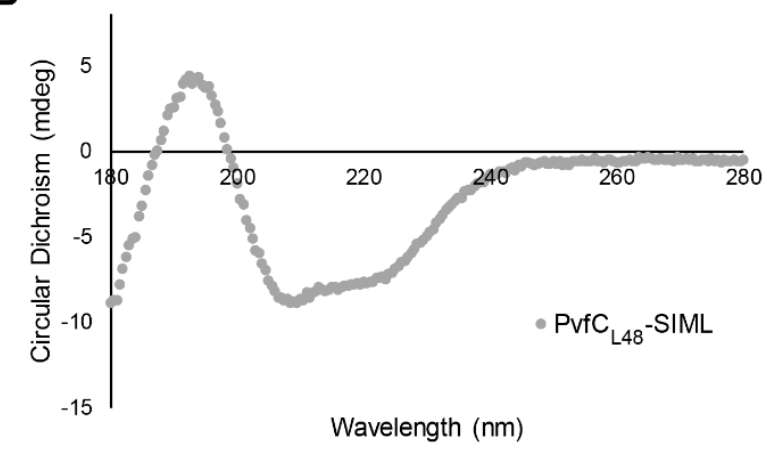

Figure S23. Circular dichroism spectra of $(A) P \mathrm{PfC}_{\mathrm{L} 48}$ and $(\mathrm{B}) \mathrm{PvfC}_{\mathrm{L} 48}-\mathrm{A} 381 \mathrm{~S}, \mathrm{L384I}$, V444M, I467L (SIML) mutant.
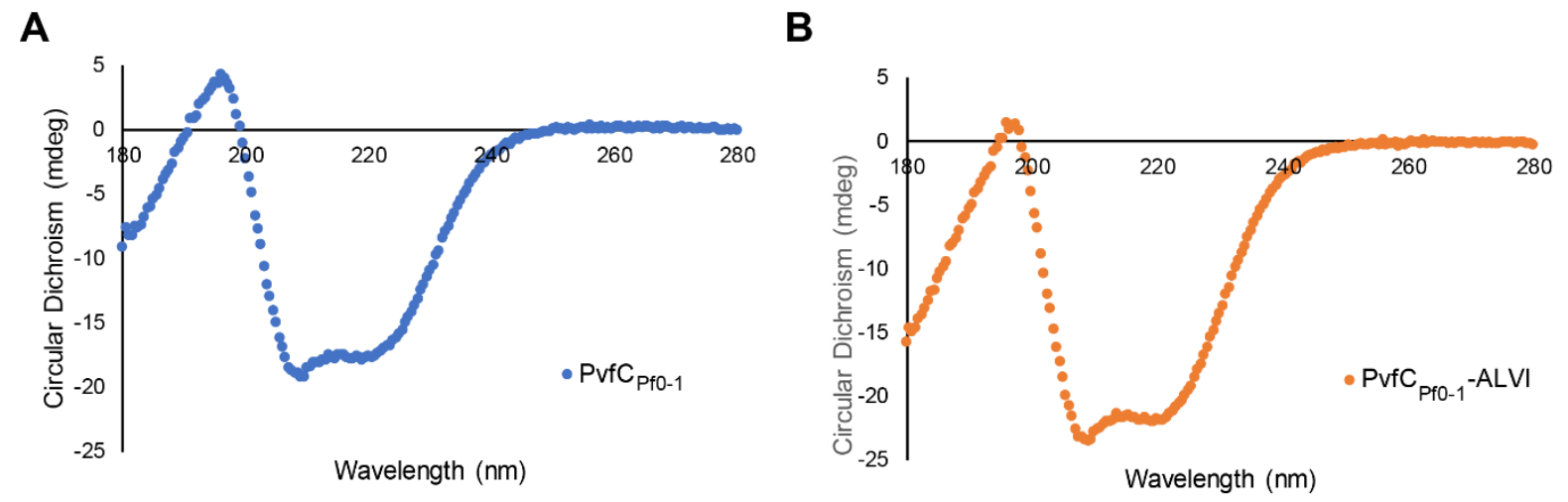

Figure S24. Circular dichroism spectra of (A) $\mathrm{PvfC}_{\mathrm{Pf0}-1}$ and (B) $\mathrm{PvfC}_{\mathrm{Pf0}-1-\mathrm{S} 366 \mathrm{~A}, \mathrm{I369}}$, M429V, L452I (ALVI) mutant. 


\section{References}

(1) Choi, K. H.; Deshazer, D.; Schweizer, H. P. (2006) Mini-Tn7 insertion in bacteria with multiple glms-linked attTn7 sites: Example Burkholderia mallei ATCC 23344. Nat Protoc 1, $162-$ 9.

(2) Choi, K. H.; Gaynor, J. B.; White, K. G.; Lopez, C.; Bosio, C. M.; Karkhoff-Schweizer, R. R.; Schweizer, H. P. (2005) A Tn7-based broad-range bacterial cloning and expression system. Nat. Methods. 2, 443-8.

(3) Choi, K. H.; Kumar, A.; Schweizer, H. P. (2006) A 10-min method for preparation of highly electrocompetent Pseudomonas aeruginosa cells: Application for DNA fragment transfer between chromosomes and plasmid transformation. J. Microbiol. Methods 64, 391-7.

(4) Medema, M. H.; Takano, E.; Breitling, R. (2013) Detecting sequence homology at the gene cluster level with MultiGeneBlast. Mol. Biol. Evol. 30, 1218-23.

(5) Winsor, G. L.; Griffiths, E. J.; Lo, R.; Dhillon, B. K.; Shay, J. A.; Brinkman, F. S. (2016) Enhanced annotations and features for comparing thousands of Pseudomonas genomes in the pseudomonas genome database. Nucleic Acids Res. 44, D646-G653.

(6) Gerlt, J. A.; Bouvier, J. T.; Davidson, D. B.; Imker, H. J.; Sadkhin, B.; Slater, D. R.; Whalen, K. L. (2015) Enzyme function initiative-enzyme similarity tool (EFI-EST): A web tool for generating protein sequence similarity networks. Biochim. Biophys. Acta. 1854, 1019-37. (7) Vallet-Gely, I.; Opota, O.; Boniface, A.; Novikov, A.; Lemaitre, B. (2010) A secondary metabolite acting as a signalling molecule controls Pseudomonas entomophila virulence. Cell. Microbiol. 12, 1666-79.

(8) Coenye, T.; Vandamme, P.; Lipuma, J. J.; Govan, J. R.; Mahenthiralingam, E. (2003) Updated version of the Burkholderia cepacia complex experimental strain panel. J Clin Microbiol 41, 2797-8.

(9) O'neill, E. M.; Mucyn, T. S.; Patteson, J. B.; Finkel, O. M.; Chung, E. H.; Baccile, J. A.; Massolo, E.; Schroeder, F. C.; Dangl, J. L.; Li, B. (2018) Phevamine A, a small molecule that suppresses plant immune responses. Proc. Natl. Acad. Sci. U. S. A. 115, E9514-E9522.

(10) Okrent, R. A.; Trippe, K. M.; Maselko, M.; Manning, V. (2017) Functional analysis of a biosynthetic cluster essential for production of 4-formylaminooxyvinylglycine, a germinationarrest factor from Pseudomonas fluorescens WH6. Microbiology 163, 207-217.

(11) Kretsch, A. M.; Morgan, G. L.; Tyrrell, J.; Mevers, E.; Vallet-Gely, I.; Li, B. (2018) Discovery of (dihydro)pyrazine $\mathrm{N}$-oxides via genome mining in Pseudomonas. Org. Lett. 20, 4791-4795. (12) Jenul, C.; Sieber, S.; Daeppen, C.; Mathew, A.; Lardi, M.; Pessi, G.; Hoepfner, D.; Neuburger, M.; Linden, A.; Gademann, K.; Eberl, L. (2018) Biosynthesis of fragin is controlled by a novel quorum sensing signal. Nat. Commun. 9, 1297. 